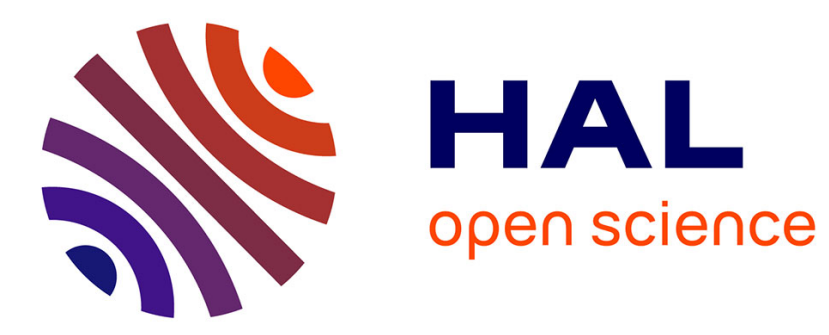

\title{
New genera Buserphites and Mesoserphites (Hymenoptera: Serphitidae) from mid-Cretaceous amber of Myanmar.
}

Mélanie C M Herbert, Ryan C Mckellar

\section{- To cite this version:}

Mélanie C M Herbert, Ryan C Mckellar. New genera Buserphites and Mesoserphites (Hymenoptera: Serphitidae) from mid-Cretaceous amber of Myanmar.. Cretaceous Research, 2022, 130, pp.105025. 10.1016/j.cretres.2021.105025 . insu-03418652

\section{HAL Id: insu-03418652 \\ https://hal-insu.archives-ouvertes.fr/insu-03418652}

Submitted on 8 Nov 2021

HAL is a multi-disciplinary open access archive for the deposit and dissemination of scientific research documents, whether they are published or not. The documents may come from teaching and research institutions in France or abroad, or from public or private research centers.
L'archive ouverte pluridisciplinaire HAL, est destinée au dépôt et à la diffusion de documents scientifiques de niveau recherche, publiés ou non, émanant des établissements d'enseignement et de recherche français ou étrangers, des laboratoires publics ou privés. 


\section{Journal Pre-proof}

New genera Buserphites and Mesoserphites (Hymenoptera: Serphitidae) from mid-

Cretaceous amber of Myanmar.

Mélanie C.M. Herbert, Ryan C. McKellar

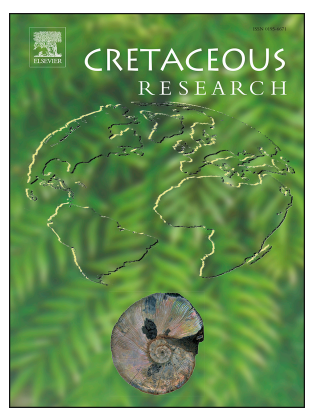

PII:

S0195-6671(21)00273-1

DOI:

https://doi.org/10.1016/j.cretres.2021.105025

Reference: $\quad$ YCRES 105025

To appear in: Cretaceous Research

Received Date: 15 December 2020

Revised Date: 30 August 2021

Accepted Date: 30 August 2021

Please cite this article as: Herbert, M.C.M., McKellar, R.C., New genera Buserphites and Mesoserphites (Hymenoptera: Serphitidae) from mid-Cretaceous amber of Myanmar., Cretaceous Research, https:// doi.org/10.1016/j.cretres.2021.105025.

This is a PDF file of an article that has undergone enhancements after acceptance, such as the addition of a cover page and metadata, and formatting for readability, but it is not yet the definitive version of record. This version will undergo additional copyediting, typesetting and review before it is published in its final form, but we are providing this version to give early visibility of the article. Please note that, during the production process, errors may be discovered which could affect the content, and all legal disclaimers that apply to the journal pertain.

() 2021 Elsevier Ltd. All rights reserved. 
1 New genera Buserphites and Mesoserphites (Hymenoptera: Serphitidae) from mid-

2 Cretaceous amber of Myanmar.

3

4 Mélanie C. M. Herbert ${ }^{\mathrm{a}, \mathrm{b}, \mathrm{c}^{*}}$, Ryan C. McKellar ${ }^{\mathrm{b}, \mathrm{c}, \mathrm{d}}$

5

$6 \quad{ }^{\text {a }}$ CNRS UMR 6118 Géosciences \& OSUR, Université de Rennes 1, Campus de Beaulieu bât. 15, 263

7 avenue du Général Leclerc, 35042 Rennes cedex, France.

$8 \quad$ boyal Saskatchewan Museum, 2445 Albert St., Regina, SK S4P 4W7, Canada.

$9{ }^{\mathrm{c}}$ Biology Department, University of Regina, Regina, Saskatchewan, S4S 0A2, Canada.

$10{ }^{\mathrm{d}}$ Division of Entomology, Natural History Museum, and Department of Ecology \& Evolutionary Biology,

111501 Crestline Drive - Suite 140, University of Kansas, Lawrence, Kansas, 66045, USA.

12 * Corresponding author. E-mail address: melaniecm.herbert@ gmail.com 


\section{Abstract}

15 Two new genera, Burserphites and Mesoserphites, belonging to the subfamily Serphitinae 16 (Serphitidae, Hymenoptera) are described from Burmese mid-Cretaceous amber. Two new 17 species are erected within Buserphites n. gen.: B. applanatus, and B. myanmarensis, and five new species are established within Mesoserphites n. gen.: M. annulus, M. giganteus, M. engeli,

$19 M$. scutatus, and $M$. viraneacapitis. These taxa show that the family Serphitidae was highly 20 diverse in Burmese amber, adding substantially to recent discoveries within the endemic 21 subfamily Supraserphitinae Rasnitsyn and Ölm-Kühnle. The presence of multiple serphitid 22 genera in Burmese amber that are unknown from other amber deposits adds support to the idea 23 that the Western Burma Block supported a fauna with multiple endemic groups as it approached 24 contact with mainland Asia in the latest Albian or earliest Cenomanian. Despite the growing 25 number of species recognized from Burmese amber, most of the newly described taxa are 26 represented by very few specimens, suggesting that we are still within the early stages of 27 documenting the fauna, or that the collections from this region represent a broader range of time 28 and habitats than originally thought. 


\section{Introduction}

33 The Serphitidae Brues, 1937 are a small family of extinct parasitic wasps that have been assigned

to the clade Bipetiolarida Engel (2005) based on the distinctive arrangement of two petiolar

35 segments observed in its members (see Rasnitsyn and Ölm-Kühnle, 2019b for alternative systematic interpretation). The first member of Serphitidae described was Serphites paradoxus

37 Brues, 1937, and the taxon was recognized as part of its own unique family at the time of its initial description. Although recognition at the family level has varied over time (e.g., Kozlov and Rasnitsyn, 1979), this small family was widespread during the Cretaceous, ranging from the Barremian to Campanian through a series several deposits: Serphitidae are known from Lebanese, Spanish, French, Siberian, Burmese, and Canadian Cretaceous amber (Brues, 1937;

42 Kozlov and Rasnitsyn, 1979; Engel et al., 2011; McKellar and Engel, 2011; Ortega-Blanco et al., 43 2011; Engel and Perrichot, 2014; Rasnitsyn and Ölm-Kühnle 2019a, 2019b, 2020a, 2020b). 44 Currently, the family comprises only three subfamilies, each with a few genera: Serphitinae 45 Brues, 1937, Microserphitinae Engel, 2015, and Supraserphitinae Rasnitsyn and Ölm-Kühnle, 46 2018. The Serphitidae in Burmese amber have not been studied in detail until recently, with the 47 last three years seeing new research by Rasnitsyn and Ölm-Kühnle (2019a, 2019b, 2020a, 2020b) that has resulted in the description of five new species based on unique female 49 specimens, and the creation of a new subfamily, Supraserphitinae, to accommodate some of these taxa. These taxa have presented characteristics of both Serphitidae and Archaeoserphitidae

51 Engel, 2015, leading the authors to question the distinction between the families recognized within Serphitoidea Brues, 1937; however, these hypotheses remain to be tested through cladistic 
54 previous work on Burmese amber serphitids, but these specimens are currently undescribed 55 (Rasnitsyn and Ölm-Kühnle, 2020b).

Mid-Cretaceous Burmese amber is now ranked among the richest deposits of amber,

57 including considerable faunal and floral biodiversity, and it provides one of the best snapshots of terrestrial conditions in the Mesozoic. A particularly diverse arthropod assemblage has been 59 described from the deposit, especially within the orders Hymenoptera, Coleoptera, and Diptera (e.g., Grimaldi et al., 2002; Ross et al., 2010; Ross, 2019, 2020). The deposit has also been the

61 source of marginal marine inclusions like ammonites and ostracods (Xing et al., 2018; Yu et al.,

62 2019), and taxa that are seldom preserved in Cretaceous resin, such as vertebrates and gastropods

63 (e.g., Daza et al., 2016; Xing et al., 2016, 2019).

64 Among the serphitoid wasps, all observations indicate that the seven new species described herein belong the subfamily Serphitinae. The taxonomic features that distinguish this subfamily 66 from others have been described at length by Engel (2015) and include possessing antennae with 676 to 8 flagellomeres. This low flagellar article count is a readily apparent characteristic of all 68 Serphitinae, and it is shared by Microserphites Kozlov and Rasnitsyn, 1979 (the sole member of 69 Microserphitinae). However, the Microserphitinae can be distinguished from Serphitinae, based 70 on the former group possessing a pronotum that does not reach the tegula, and an indistinct 71 pterostigma. Supraserphitinae have been described from Burmese amber, and are known 72 exclusively from female specimens, but all available material demonstrates 10 flagellar articles.

73 The family Archaeoserphitidae differs in that its members have 12 flagellomeres, a pronotum 74 reaching the tegula, and a distinct pterostigma. The member of Archaeoserphitidae that was 75 recently described from Burmese amber (i.e., Archaeoserphites engeli Rasnitsyn and Ölm76 Kühnle, 2020a) differs from the type species of the genus and in many details of the generic 
77 diagnosis, beyond the extent of sexual dimorphism observed elsewhere in the Serphitoidea,

78 perhaps warranting the erection of additional taxa within the deposit.

79 Among the Serphitinae, the specimens described herein belong in two new genera:

80 Buserphites and Mesoserphites. The new genus Buserphites can be distinguished from

81 previously described Serphitidae based on the presence of an elongate petiolar segment (first

82 segment is more than three times the length of the second). Meanwhile the new taxon

83 Mesoserphites presents an intermingling of characteristics that have been previously attributed to

84 the genera Serphites and Aposerphites Kozlov and Rasnitsyn, 1979. Relationships among the

85 previously described genera of Serphitinae (Aposerphites, Serphites, and Jubaserphites McKellar

86 and Engel, 2011) have not been assessed through cladistic analyses because of the low taxon

87 sampling density that is currently available. However, it is hoped that continued work on

88 Burmese amber exemplars will provide sufficient material to analyze Serphitidae in detail, and to

89 assess the extent of faunal overlap or endemism that occurs in the Cretaceous deposits where 90 they occur.

\section{2. Material and methods}

93 The insect inclusions in this study come from 13 specimens of mid-Cretaceous Burmese amber.

94 Seven of these specimens come from the Royal Saskatchewan Museum collection (RSM, 95 RSKM_P specimen numbers, Regina, SK, Canada) and contain individual serphitids, with the 96 exception of RSKM_P3306.30, which has 3 syninclusions belonging to two different species.

97 Five additional specimens belong to the American Museum of Natural History (AMNH, AMNH_Bu specimen numbers, New-York, NY, USA). All fossil inclusions are commercial 99 specimens collected in the Hukawng Valley, in Myanmar's Kachin state (Grimaldi et al., 2002; 
100 Cruickshank and Ko, 2003; Ross et al., 2010; Li et al., 2018). Radiometric dates $\left({ }^{206} \mathrm{~Pb} /{ }^{238} \mathrm{U}\right)$

101 obtained from zircons attached to amber pieces in this mining region have established a date for

102 the rocks surrounding the Burmese amber deposit that is $98 \pm 0.62 \mathrm{Ma}$, or latest Albian to

103 earliest Cenomanian (Shi et al., 2012); however, the amber deposit may represent a broader

104 window of time around this time estimate (e.g., Smith and Ross, 2018, Yu et al., 2019).

105 Amber specimens were polished to create ideal anatomical views of inclusions, and 106 whenever necessary, specimens were supported by vacuum-injection with epoxy prior to 107 polishing (following the technique of Nascimbene and Silverstein, 2000). Specimen photographs 108 were taken with a Canon EOS 7D camera and EF $65 \mathrm{~mm}$ macro lens mounted on a Visionary 109 Digital imaging station. The resulting series of photos taken at different levels were combined 110 with Helicon Focus software to increase depth of field. Specimen observations were made using 111 a Leica MZ 12.5 stereomicroscope, and an Olympus CH30 compound microscope was used for 112 supplementary observations. All measurements were obtained with an ocular micrometre and are 113 expressed in millimetres in the text. Whenever possible, general measurements were taken in 114 lateral view to account for curvature of the body, and more precise measurements were taken by 115 mounting the amber specimen in wax to obtain whatever orientation was required to create an 116 accurate measurement.

117 The morphological descriptions are based on articles previously published on the 118 superfamily Serphitoidea, as well as the larger-scale work of Goulet and Huber (1993). Harris 119 (1979) is used to describe surface sculpturing, and our use of venation terminology is explained 120 in Figure 1. Anatomical abbreviations include: ba., basitarsus; cx., coxa; fe., femur; fla., 121 flagellomeres; mlt., lateral marge between tergites and sternites; msp., mesopleuron; mst., 122 mesoscutum; mstl., mesoscutellum; mtn., metanotum; oce., ocellus; OD, ocellar diameter; ped., 
123 pedicel; ppd., propodeum; pro., pronotum; sca., scape; ster., sternite; ta., tarsus; ter., tergite; ti.,

124 tibia; tr., trochanter; ver., vertex. Where males and females have been attributed to the same 125 species without direct associations (syninclusions), a section at the end of the description details 126 differences found in the males.

\section{3. Identification key to genera of Serphitinae}

129 The key to the genera of Serphitidae is modified from the works of Kozlov and Rasnitsyn 130 (1979), Ortega-Blanco et al. (2011), and McKellar and Engel (2011) in order to cover recent 131 developments within the subfamily Serphitinae. Members of the subfamily Supraserphitinae are 132 readily distinguished by their 10 flagellar articles, and are diagnosed in the works of Rasnitsyn 133 and Ölm-Kühnle (2019a, 2019b, 2020b).

135 1. Flagellum with six articles; vertex with elongate, erect setae [Campanian; Canadian 136 amber] Jubaserphites

$138 \quad-\quad$ Flagellum with more than six articles; vertex with short, inclined setae, or bare 2

1412 Pronotum not reaching tegula; pterostigma indistinct, represented by diffuse fuscous area at apex of $\mathrm{Sc}+\mathrm{R}$; tergum with first three tergites of similar lengths [Albian-Santonian; Spanish, Siberian amber, and Burmese amber (pers. obs.)] Microserphites 
$145 \quad$-- $\quad$ Pronotum reaching tegula; pterostigma distinct and sclerotized; tergum with first three tergites of different lengths.

147 148

149 3

3. Mesoscutellum slightly convex or straight; first petiolar segment length more than three times that of second petiolar segment [Albian-Cenomanian, Burmese amber] Buserphites gen. $\mathbf{n}$.

-- Mesoscutellum convex or highly convex; first petiolar segment length three times or less than that of second petiolar segment 4

4. First petiolar segment length two or more times that of second petiolar segment; male antenna clubbed; lateral ocellus nearly touching or touching compound eye margin (most species), or, if ocellus widely separated, first petiolar segment nearly three times as long as second segment (Serphites kuzminae) [Albian-Santonian; Spanish, New Jersey, Canadian, Siberian, and Burmese amber (pers. obs.)] Serphites

First petiolar segment length less than twice that of second petiolar segment; male antenna not clavate; lateral ocellus not touching margin of compound eye ...................... 5

5. Lateral ocellus nearly touching compound eye margin, separated by less than one-half ocellar diameter; clypeus dorsoventral length significantly shorter than lateral width; antennae arising near ventral margin of compound eye [Albian-Cenomanian, Burmese 
n.

-- Lateral ocellus separated from compound eye margin by one-half ocellar diameter or more; clypeus length similar to width; antennae arise just below mid-height of compound eye [Albian-Santonian; Spanish, Siberian amber, and Burmese amber (pers. obs.)] .... Aposerphites

\section{Systematic palaeontology}

Superfamily Serphitoidea Brues, 1937

Family Serphitidae Brues, 1937

Subfamily Serphitinae Brues 1937

\section{Genus Buserphites n. gen.}

(urn:1sid:zoobank.org:act:62611C21-654D-4E76-AC29-8FE28FC7523D)

Diagnosis. Flagellum with 7 or 8 flagellar articles; first flagellar article shortest, and flagellum broadest near midlength; lateral ocellus separated from compound eye by more than 0.5 OD (nearly touching in Serphites, and Mesoserphites n. gen.); antennae insert near anteroventral margin of compound eye; mandibles strongly curved, protuberant when closed; hind wing with 2 Rs reaching $2 \mathrm{M}$; mesoscutellum slightly convex or straight; first petiolar segment length more than three times that of second petiolar segment; second petiolar segment nearly cylindrical and with faint longitudinal striations. 
Etymology. The new genus name is a combination of the Latin adjective $b u$ - meaning "large, huge, great", which refers to the proportion between the first petiolar segment length and the second segment, combined with -serphites, a common suffix for Serphitidae, based on the type species; the name is masculine.

Type species. Buserphites applanatus gen. et sp. n.

Included species. Two species in Albian-Cenomanian Burmese amber: B. applanatus gen. et sp. n., and B. myanmarensis gen. et sp. n.

Remarks. If members of this genus attained very small body sizes (with reduced venation), they may be difficult to distinguish from species of Microserphites.

Buserphites applanatus gen. et sp. n.

(urn:lsid:zoobank.org:act:F2928524-EDDF-46BB-8519-A3321326F9B2)

Material examined. Holotype AMNH_Bu-1512 (female). Polished amber piece including support epoxy, one of three amber pieces cut from larger amber sample, with dimensions of 11.6 $\mathrm{mm} \times 5.2 \mathrm{~mm} \times 2.7 \mathrm{~mm}$; amber is yellow with flow lines and with high particulate content. Etymology. New species name refers to mesosoma-shape, using the Latin adjective applanatus, which means "flattened".

Type locality. Hukawng Valley, Kachin State, in Myanmar, near Tanai Village (on Ledo Road 105 km NW of Myitkyna), Myanmar, Upper Cretaceous.

Diagnosis. New species is generally similar to other species of Buserphites (B. myanmarensis), but differs in following combination of characters: compound eye occupying approximately one- 
213 half of head in lateral view; ocelli almost forming equilateral triangle (possibility affected by

214 antero-posterior taphonomic head compression); lateral ocelli separated from compound eye

215 margin by $1 \mathrm{OD}$, ovate; antennae with 8 flagellomeres (in female); scape somewhat globose, not

216 reaching vertex, and approximately 2.7 times longer than its greatest width; mandibles deeply

217 divided, with elongate, pointed teeth; right mandible with 3 teeth, middle tooth shortest, ventral

218 tooth longer and thinner than others, and with broad base; left mandible with 2 teeth, slender

219 throughout lengths, with ventral tooth significantly longer than dorsal tooth; transition between

220 dorsal surface and declivity on propodeum rounded, convex; forewing with nebulous $\mathrm{C}$ and

221 highly sclerotized pterostigma; pterostigma with globose, triangular posterior expansion of

222 fuscous area adjacent to r-rs and Rs veins; Sc+R not contacting 1Rs; 1Rs forming bulbous

223 prestigmal expansion, not truncated before contact with pterostigma; $\mathrm{M}+\mathrm{Cu}$ broad and fuscous

224 apically, becoming spectral; $1 \mathrm{~m}$-cu as wide as $\mathrm{Cu}$, width extending, after reaching $2 \mathrm{M}$; $3 \mathrm{M}$

225 relatively straight; $\mathrm{Cu}$ shorter than combined $1 \mathrm{M}$ and $1 \mathrm{Rs}$, and terminates in $\mathrm{CuP}$; vein $\mathrm{A}$ with

226 distal portions slender, spectral, bearing row of thickened, long, inclined microtrichia; hind wing

227 with only anterior vein visible $(\mathrm{Sc}+\mathrm{R})$; metasoma with gaster as long as mesosoma; first petiolar

228 segment about 3.2 times length of second segment.

229

230 Description. Total body length $\sim 1.86 \mathrm{~mm}$; mesosoma $\sim 0.68 \mathrm{~mm}$ in length; forewing $\sim 0.94 \mathrm{~mm}$

231 long and $\sim 0.43 \mathrm{~mm}$ wide; hind wing $\sim 0.68 \mathrm{~mm}$ long, $\sim 0.34 \mathrm{~mm}$ wide; metasoma $\sim 0.73 \mathrm{~mm}$ long;

232 gaster $\sim 0.50 \mathrm{~mm}$ long (Fig. 2).

233 Head: appears wider than long, but is taphonomically compressed; compound eye with rounded

234 margins and apparently globose (also taphonomically compressed), bearing numerous erect, fine

235 setae; gena gently inflated, bearing numerous semi-erect, fine setae; median ocellus slightly 
236 larger than lateral ocellus (greater in diameter), and separated from lateral ocellus by 1 OD;

237 lateral ocellus ovate, and separated from compound eye by 1 OD; antenna with 8 flagellar

238 articles that are weakly clavate and broadest near midlength of flagellum; antennae compressed

239 antero-posteriorly; flagellar articles approximately: 18, 32, 43, 47, 47, 51, 49, and $56 \mu \mathrm{m}$ in

240 length; scape approximately $85 \mu \mathrm{m}$ long and $32 \mu \mathrm{m}$ wide; pedicel approximately $55 \mu \mathrm{m}$ long;

241 first flagellar article semi-clavate and shortest; subsequent flagellar articles flattened and club-

242 shaped; apical flagellar article longest and terminating in rounded point; pedicel clavate and

243 relatively short, narrower than flagellar articles. Maxillary palpus nearly as long as mandible,

244 terminating in long, slender palpomere; labial palpus apparently 3-segmented, with terminal

245 palpomere spear-shaped, highly inflated, and with acute point.

246 Mesosoma: dorsoventrally compressed, dark and without clear surface structure visible;

247 mesoscutum with punctuate surface structure, and without notauli visible; mesoscutellum

248 flattened, sunken compared to mesoscutum; propodeum moderately convex, apparently with

249 foveolate-rugulose surface structure.

250 Wings: orientation and curvature of wings renders observation difficult. Forewing with 251 pterostigma shaped like equilateral triangle, with half of anterior margin more deeply pigmented;

252 pterostigma with convex anterior margin (vein R), slightly concave basal margin (1r-rs), and 253 nearly straight apical margin (2r-rs); R fuscous; nebulous 2Rs extending adbasally from 254 pterostigma, forming long prestigmal expansion, and apparently reaching 2M; 3Rs nebulous, 255 extending apically from pterostigma, short, relatively straight, and reaching near wing apex; 1R 256 tubular, fuscous, not extending beyond pterostigma; nebulous $\mathrm{C}$ and tubular $\mathrm{Sc}+\mathrm{R}$, both equal in 257 width, veins nearly straight, and separated by wide costal cell; costal cell base and apex equal in 258 width, little more than two times width of $\mathrm{C}$ vein; $\mathrm{Sc}+\mathrm{R}$ and $\mathrm{C}$ complete to base of wing; tubular, 
curved $\mathrm{M}$, equal to $\mathrm{Sc}+\mathrm{R}$ in width; $\mathrm{Sc}+\mathrm{R}$ tubular, not fusing apically with bulbous $1 \mathrm{Rs} ; \mathrm{M}+\mathrm{Cu}$ contacting $\mathrm{Sc}+\mathrm{R}$ midway through its length; $2 \mathrm{M}$ thinner basally than apically, reaching wing margin apically and reaching $2 \mathrm{Rs}$ basally; $2 \mathrm{M}$ with straight basal section; $\mathrm{Cu}$ equal to $1 \mathrm{M}$ in width, and terminating in $\mathrm{CuA}$; $\mathrm{CuA}$ tubular, slender, highly curved posteriad basally (withinapical one-third of posterior wing margin), straight and reaching posterior wing margin apically. Vein A with distal portions slender, spectral, and bearing row of thicker, long, inclined microtrichia.

Legs: slightly compressed, long; base of legs covered by inclined setae; trochanters extremely short, especially protrochanter, which superficially appears absent; profemur comparatively long, metafemur slightly shorter than others and significantly broader; tibiae very long; tibial spur formula 1-2-2, with protibial spur curved, fine, and long, while meso- and metatibial spurs are relatively straight and slightly shorter; basitarsus shorter than cumulative length of other tarsomeres; tarsomeres I and IV longer than II and III, and III is shortest tarsomere; pretarsus long, with short and simple claws.

Metasoma: with combined length of petiolar segments slightly less than two-thirds of gastral length; first petiolar segment markedly long, cylindrical; surface of first petiolar segment with numerous, prominent, longitudinal carinae separated by fossulate sulci; second petiolar segment broader than first petiolar segment, but with surface details difficult to observe, apparently cylindrical with faint longitudinal striations; gaster compressed ventrodorsally, dark and without clear surface structure visible; gaster ovate in dorsal view; tergum with six apparent tergites, with first tergite longer than second, and bearing fine punctures and minute, inclined setae; first three tergites comprise less than half of gastral length; sternum with four apparent sternites, with first sternite longer than second; lateral margins between tergites and sternites appear to have well- 
282 developed laterotergites, visible as bulbous carina with five segments. Female genitalia with 283 paramere clavate, apex moderately expanded.

Buserphites myanmarensis gen. et sp. n.

287 (urn:lsid:zoobank.org:act:4141CD5B-1A6C-4A9C-B99E-6708C144BA73)

Material examined. Holotype RSKM_P3306.61 (probable female). Polished amber piece 290 including support epoxy, with dimensions of $8.6 \mathrm{~mm}$ x $7.9 \mathrm{~mm} \times 4.7 \mathrm{~mm}$; amber is orange with 291 multiple, darkly oxidized flow lines.

292 Etymology. Species name refers to country of origin, Myanmar.

293 Type locality. Hukawng Valley, Kachin State, in Myanmar, upper Albian-lowermost 294 Cenomanian.

Diagnosis. New species similar to other species of Buserphites, but differs in following 297 combination of characters: compound eye occupying approximately one-third of head in lateral 298 view; ocelli forming isosceles triangle; lateral ocelli separated from compound eye margin by 0.5 299 OD, ovate, canted posterolaterally, and separated by 4 OD from median ocellus; antennae 300 (female) with 7 flagellomeres; scape approximately four times longer than its greatest width; 301 mandibles deeply divided, with pointed, stout, elongate, and highly curved teeth, and bearing 302 relatively long setae on both outer and inner surfaces of teeth; right mandible apparently bears 303 three teeth, with dorsal and middle teeth diminutive, and ventral tooth most prominent, long and 304 slender; left mandible appears to have two teeth and narrow base; mesosoma with transcutellar 
furrow bearing two broad foveae medially, and with finer punctures laterally; transition between dorsal surface and declivity on propodeum marked by strong lateral protuberance; forewing with pterostigma weakly sclerotized and tubular $\mathrm{C}$ vein; pterostigma with wide, long, tubular posterior expansion of fuscous area adjacent to r-rs crossvein and Rs vein; Sc+R contacting $1 \mathrm{Rs}$ and forming bulbous prestigmal expansion, slightly truncated before contact with pterostigma; $\mathrm{M}+\mathrm{Cu}$ spectral; 1m-cu may be present, but spectral; $3 \mathrm{M}$ sinuous; $\mathrm{Cu}$ length equal to that of $1 \mathrm{M}$ and $1 \mathrm{Rs}$ combined; $\mathrm{Cu}$ not terminating in $\mathrm{CuP}$; vein $\mathrm{A}$ apparently absent; legs with trochanters long and

312 globose, with two longitudinal carinae; basitarsus slightly shorter than cumulative length of other 313 tarsomeres; metasoma with gaster slightly longer than mesosoma; first petiolar segment 314 comparatively long, about 3.4 times length of second segment; first tergite extending ventrally, 315 partially enclosing second petiolar segment.

317 Description. Total body length $\sim 1.97 \mathrm{~mm}$; mesosoma $\sim 0.70 \mathrm{~mm}$ in length; forewing $\sim 1.21 \mathrm{~mm}$ 318 long, and $\sim 0.30 \mathrm{~mm}$ wide; hind wing $\sim 0.42 \mathrm{~mm}$ long, and $\sim 0.10 \mathrm{~mm}$ wide; metasoma $\sim 1.09 \mathrm{~mm}$ 319 in length; gaster $\sim 0.75 \mathrm{~mm}$ long (Fig. 3).

320 Head: wider than long; compound eye teardrop-shaped, slightly globose posteriorly, with 321 relatively straight margin adjacent to gena, and bearing numerous, erect, fine setae; gena 322 flattened, with areolate-rugulose surface structure; frons straight, and not sunken relative to 323 compound eyes; vertex mounded between lateral ocelli with few punctations; median ocellus 324 same size as lateral ocellus, and separated from lateral ocellus by 3 OD; antenna 9-segmented, 325 and weakly clavate; scape approximately $136 \mu \mathrm{m}$ long and $33 \mu \mathrm{m}$ wide, scape length 326 approximately four times its greatest width; pedicel approximately $67 \mu \mathrm{m}$ long, pear-shaped, and 327 slightly longer than third flagellar article; flagellar articles with flattened posterior edge, and 
measuring approximately: 50, 55, 64, 61, 59, 61, and $90 \mu \mathrm{m}$ in length; first flagellar article semiclavate and shortest; second flagellar article clavate; subsequent flagellar articles chalice-like and equant; apical flagellar article elongate, and terminating in acute point. Maxillary palpus apparently shorter than mandible, four-segmented, and geniculate between second and third palpomeres, terminal palpomere longest, with acute point.

Mesosoma: with pronotum steeply sloping anteriorly, almost concealed by mesoscutum in dorsal view, and with tiny foveate surface structure; mesoscutum highly convex, shield-shaped, with lateral margins angular, with tiny foveate surface structure, and with notauli; notauli broad, shallow, and difficult to observe, apparently with curved line of fovea in sulcus; notauli converging posteriorly, forming broad V-shape, which is pointed near anterior margin of mesoscutellum; mesoscutellum flattened, sunken compared to mesoscutum, with areolaterugulose surface structure anteriorly and foveate-reticulate posteriorly, with fine carina separating mesoscutellum from propodeum; metanotum present as very fine lip posterior to mesoscutellum; propodeum slightly convex, situated well ventral to metanotum, with broad foveate surface structure, and with strong posteriorly sloping declivity.

Wings: difficult to observe due to orientation and curvature. Forewing with pterostigma shaped like equilateral triangle, with weakly sclerotized and slightly concave basal margin (1r-rs), convex anterior margin (R), slightly concave basal margin (1r-rs), and nearly straight apical margin (2r-rs); pterostigma with wide, long, tubular, posterior expansion of fuscous area adjacent to r-rs and Rs veins; 2Rs extending adbasally from pterostigma, forming slender, long expansion, and apparently reaching $2 \mathrm{M}$; 3 Rs extending apically from pterostigma, slightly curved (convex anteriorly), short, and nearly reaching wing anterior margin apically; $1 \mathrm{R}$ tubular, fuscous, not extending beyond pterostigma; tubular $\mathrm{C}$ and tubular $\mathrm{Sc}+\mathrm{R}$, both equal in width and nearly 
351 straight, separated by wide costal cell; costal cell base and apex equal in width, slightly more

352 than two times width of $\mathrm{C}$ vein; $\mathrm{Sc}+\mathrm{R}$ and $\mathrm{C}$ extending basally to reach wing margin; $1 \mathrm{M}$

353 tubular, equal to $\mathrm{Sc}+\mathrm{R}$ in width, relatively straight; $\mathrm{M}+\mathrm{Cu}$ contacting $\mathrm{Sc}+\mathrm{R}$ midway through its

354 length; $\mathrm{Cu}$ equal to $1 \mathrm{M}+1 \mathrm{Rs}$ in width, and terminating in $\mathrm{CuA}$; $\mathrm{CuA}$ tubular, slender, slightly

355 curved posteriad basally, straight apically, and reaching posterior wing margin apically. Hind

356 wing difficult to observe; basal wing with anterior (probable Sc+R) and posterior (probable A)

357 vein, but both appear to fade quickly adapically.

358 Legs: covered by numerous, inclined, fine, short setae; mesocoxa ovate, and metacoxa elongate

359 with strong longitudinal depression in basal half of ventral surface; pro- and meso-trochanter

360 slightly bell-shaped while metatrochanter ovate with protuberance in middle; femora short, and

361 broad, especially in apical area, which is laterally compressed; tarsi longer than corresponding

362 femora; all tibiae flared apically; pro- and mesotibiae laterally compressed, metatibia swollen

363 apically; protibia with two carinae extending longitudinally along dorsal surface; protibia with

364 single apical spur that is straight and as long as tibial apex is wide; mesotibia with two apical

365 spurs, anterior spur length approximately equal to apical tibial width, posterior spur

366 approximately double this length; metatibia with two short, robust spurs that appear to be shorter

367 than apical width of metatibia; pro- and metabasitarsus slightly shorter than cumulative length of

368 other tarsomeres, while mesobasitarsus shorter than cumulative length of other tarsomeres;

369 tarsomeres I and IV longer than II and III, and III is shortest tarsomere

370 Metasoma: with combined length of petiolar segments slightly less than two-thirds of gastral

371 length; first petiolar segment comparatively shorter, about 3.4 times length of second; first

372 petiolar segment with fine longitudinal carinae, and expanded posteriorly, with concave ventral

373 margin; second petiolar segment, difficult to observe, apparently cylindrical with faint 
374 longitudinal striations, segment may be slightly inset into dorsal margin of first petiolar segment;

375 gaster in dorsal view teardrop-shaped, and in lateral view it appears slightly flattened dorsally

376 and convex ventrally; tergum with six apparent segments, with second tergite longest, and first

377 tergite extensively overlapping second petiolar segment (forming hood-like cover), with patch of

378 foveate integument; other tergites with punctured surface structure, and second tergite with

379 transverse row of fovea along posterior margin; sternum with four apparent (visible) segments,

380 with second sternite longest; lateral margin between tergites and sternites apparently separated

381 by carina that extends posteriorly from lateral margins of tergite 1 . Genitalia not everted, but 382 apex of ovipositor visible; very short ovipositor sheath appears to be protruding from distal end 383 of metasoma (probable female specimen).

Genus Mesoserphites n. gen.

Etymology. The new genus name is a combination of the Latin adjective meso meaning "middle" refers to the mixture of characters between the genera Serphites and Aposerphites, combined with -serphites a common suffix for Serphitidae; the name is masculine.

392 Diagnosis. Lateral ocellus nearly touching or touching compound eye margin; clypeus inclined 393 and dorsoventrally short; antennae insert near anteroventral margin of compound eye; mandibles 394 overlap when closed, non-protuberant; pronotum reaching tegula and pterostigma distinct; first 395 petiolar segment less than 2 times length of second segment; gaster with different lengths 396 between first three terga, which cover more than half of gastral length. 
Type species. Mesoserphites annulus gen. et sp. n.

398 Included species. Five new species in Burmese Albian-Cenomanian amber described herein: $M$.

399 viraneacapitis, $M$. engeli, M. giganteus, M. annulus, and M. scutatus.

400

401 Key to species of Mesoserphites n. gen.

402

403 1. Head slightly longer than wide; first petiolar segment length less than 1.5 times length of 404 second petiolar segment; first petiolar segment rimmed anteriorly; first petiolar segment with ring-like expansion posteriorly; first petiolar segment without hamulus

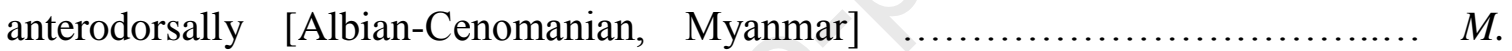
viraneacapitis $\mathbf{n}$. sp.

$408 \quad$-- $\quad$ Head as long as wide, or wider than long; first petiolar segment length more than 1.5 times that of second petiolar segment; first petiolar segment not rimmed anteriorly; first petiolar segment without ring-shaped posterior expansion; first petiolar segment with hamulus anterodorsally

2. Gaster longer than mesosoma; second petiolar segment with broad hook-like projection posteroventrally; sulcus near transscutal line shallow and weakly developed [Albian-

418 -- Gaster shorter than mesosoma; second petiolar segment without broad hook-like projection posteroventrally; sulcus along transscutal line broad and well-developed 
422 3. Tarsi slightly shorter than corresponding femora; total body length more than $3 \mathrm{~mm}$; second petiolar segment without ring-like expansion posteriorly [Albian-Cenomanian,

$426 \quad--\quad$ Tarsi as long as or longer than corresponding femora; total body length less than $2.5 \mathrm{~mm}$;

430 4. Mesocoxa with two central longitudinal carinae on lateral surface; second petiolar segment cylindrical with broad ring-like expansion posteriorly; total body length less

$434 \quad--\quad$ Mesocoxa without two central longitudinal carinae on lateral surface; second petiolar segment cylindrical with narrow collar posteriorly; total body length less than $2 \mathrm{~mm}$ sp.

440 Mesoserphites annulus gen. et sp. n.

441 (urn:Isid:zoobank.org:act:BA204CB5-3BB8-41A0-B3E5-C754358F51E0) 
443 Material examined. Holotype RSKM_P3306.60 (male). Polished amber piece including support

444 epoxy, one of four amber pieces cut from original block, with dimensions of $17.1 \mathrm{~mm} \times 10.0 \mathrm{~mm}$

$445 \times 6.9 \mathrm{~mm}$; amber is clear yellow-orange and flow lines indicate runnel on one side of piece.

446 Etymology. The new species name refers to the ring-like expansion present near the posterior

447 margin of the second petiolar segment. It is based on the Latin word for "ring or circle", annulus;

448 name is masculine.

449 Type locality. Hukawng Valley, Kachin State, in Myanmar, upper Albian-lowermost

450 Cenomanian.

451

452 Diagnosis. Unique characters of the new species that distinguish it from congeners include:

453 scape approximately 1.6 times longer than its greatest width; tarsi as long as corresponding

454 femora; pronounced lateral sulcus between tergites and sternites, which may overarch

455 laterotergites (narrow carina present in M. giganteus, and M. viraneacapitis); second petiolar

456 segment with slender, ring-like posterior margin (not present in all other Mesoserphites).

457 Differential characters include: total body length $\sim 2.1 \mathrm{~mm}$; head wider than long; compound eye

458 occupying approximately two-thirds of head in lateral view; ocelli forming weakly isosceles

459 triangle; right mandible with three teeth progressively elongated ventrally, with gap between

460 ventral and middle tooth; left mandible with two broad-based teeth, and with ventral tooth

461 slightly more robust and elongate; gaster significantly shorter than mesosoma; sternum with six

462 visible segments; first petiolar segment shorter, about 1.7 times length of second segment; first

463 petiolar segment without globose, ring-like posterior part, and not rimmed anteriorly; first

464 petiolar segment with hamulus anterodorsally. 
Description. Total body length $\sim 2.10 \mathrm{~mm}$; mesosoma $\sim 1.05 \mathrm{~mm}$ in length; forewing $\sim 1.03 \mathrm{~mm}$ long, and $\sim 0.52 \mathrm{~mm}$ wide; hind wing $\sim 0.58 \mathrm{~mm}$ long, and $\sim 0.21 \mathrm{~mm}$ wide; metasoma $\sim 0.83 \mathrm{~mm}$ in length; gaster $\sim 0.43 \mathrm{~mm}$ long (Fig. 4).

469 Head: wider than long; in lateral view, compound eye rounded and globose, bearing numerous, 470 small, erect, fine setae; frons straight, slightly sunken; vertex with scabrous surface structure 471 (possibly due to taphonomic deformation), and highly mounded between lateral ocelli; gena 472 moderately inflated laterally, with punctured surface structure, and bearing suberect, short, fine 473 setae; gena moderately inflated near vertex; median ocellus apparently twice size of lateral 474 ocellus, and separated from lateral ocellus by 4 OD; lateral ocelli nearly touching compound eye 475 margin, and separated by 5 OD; antenna 9-segmented, and clavate; flagellar articles measuring 476 approximately: $80,61,57,62,69,66$, and $113 \mu \mathrm{m}$; pedicel measuring approximately $82 \mu \mathrm{m}$; 477 scape measuring approximately $137 \mu \mathrm{m}$ long and $86 \mu \mathrm{m}$ wide; first flagellar article longest and 478 bell-shaped semi-clavate; subsequent flagellar articles nearly square in outline, with rounded479 edge; apical flagellar article terminates in rounded, blunt point; pedicel slightly longer than first 480 flagellar article. Mandibles robust and deeply divided, with elongate and pointed teeth; right mandible with teeth that progressively diminish in size dorsally, with ventral tooth longest and 482 slender, and middle tooth broader; left mandible with long and curved teeth; maxillary palpus 483 four-segmented, and geniculate between second and third palpomere, with terminal palpomere 484 forming elongate, acute point; maxillary palpus significantly longer than labial palpus, but only 485 three-quarters of length of mandible.

486 Mesosoma: has mesoscutum with areolate-rugulose to minutely colliculate surface structure; 487 mesoscutellum with areolate-rugose surface structure; mesopleuron flattened in ventral half, with 488 row of fovea in external outline, and swollen in dorsal half with rugulose-lacunose surface 
structure; metanotum with scrobiculate surface structure (transverse row of shallow foveae separated by strong carinae); propodeum with rugulose surface structure.

Wings: forewing with pterostigma shaped like equilateral triangle, with 1rs-r curved and 2rs-r straight; pterostigma with slender and long, posterior expansion of fuscous area adjacent to r-rs and Rs; 2Rs nebulous, extending straight adbasally from pterostigma, vein long but expanding,

494 and fading before reaching $\mathrm{M}$; 3Rs extending apically from pterostigma, forming curved 495 expansion and reaching anterior wing margin apically; $\mathrm{C}$ nebulous, straight and broad; costal cell wider apically, with width approximately three times that of $\mathrm{C}$, and narrower basally (slightly more than one width of $\mathrm{C}$ ); tubular $1 \mathrm{M}$ slightly wider than tubular $\mathrm{Sc}+\mathrm{R}$; $\mathrm{Sc}+\mathrm{R}$, straight, fusing apically with bulbous $1 \mathrm{Rs}$, and truncated in contact with pterostigma; $\mathrm{Sc}+\mathrm{R}$ basally reaching $\mathrm{C}$

499 before bend; $\mathrm{M}+\mathrm{Cu}$ spectral, curved and reaching $1 \mathrm{M}$ and $\mathrm{Cu}$ apically; $2 \mathrm{M}$ distally nebulous and 500 straight; $1 \mathrm{~m}$-cu spectral; $\mathrm{Cu}$ relatively straight and terminating in $\mathrm{CuP}$ and $\mathrm{CuA}$; $\mathrm{CuA}$ nebulous, 501 basally straight, fuscous, and broad, then curving posteriad, thinning gradually to reach wing 502 apex; CuP fading before reaching A; A nearly straight and tubular. Hind wing lanceolate; 503 nebulous Sc+R nearly straight; $\mathrm{R}$ wider than $\mathrm{Sc}+\mathrm{R}$, with three hamuli; Rs crossvein spectral and 504 fading rapidly basally.

505 Legs: moderately robust; pro- and mesotrochanter long and bell-shaped, while metatrochanter 506 slightly longer and more clavate; protibia with two, long, straight spurs; calcar bifid near apex; 507 metatibia with one straight apical spur, which is finer and shorter than mesotibial spur; metatibia 508 wider than mesotibia apically, also with rows of spines near apex, which become elongate 509 (almost equal to length of spur) near posteroventral margin; basitarsus with sparse, semi-erect 510 setae; meso- and metabasitasus as long as other tarsomeres' combined length, while 511 probasitarsus shorter; tarsomeres I and II longer than III and IV, and III smallest tarsomere; pro- 
512 and mesopretarsi with claws as long as arolium, while metapretarsus with finer and shorter 513 claws.

514 Metasoma: with gaster more ovate than teardrop-shaped in ventral view; gaster bare, swollen 515 anterodorsally, and straight ventrally in lateral view; tergum with five segments visible, first 516 slightly longer than second; length of petiolar segments equal to gastral length; first petiolar 517 segment cylindrical, with few, prominent, longitudinal carinae, and with fossulate, wide, deep, 518 sulci between, approximately one on each edge; first petiolar segment slightly wider anteriorly, 519 with pronounced anterior lip on dorsalmost margin; second petiolar segment cylindrical with 520 punctures. Male genitalia with parameres clavate, apex moderately expended; penis valves 521 gently swollen posteriorly.

524 Mesoserphites giganteus gen. et sp. n.

525 (urn:lsid:zoobank.org:act:A596C263-1C97-485A-99A0-3C41E07E4641)

527 Material examined. Holotype RSKM_P3306.63 (female); paratype AMNH_BU 667 (male). 528 RSKM_P3306.63 is polished amber piece including support epoxy, one of four amber pieces cut 529 from original amber specimen, with dimensions of $21.0 \mathrm{~mm} \times 15.3 \mathrm{~mm} \times 8.4 \mathrm{~mm}$; amber is clear 530 yellow-orange with multiple layers. AMNH_BU 667 is polished amber piece embedded in 531 support epoxy with dimensions of $11.1 \mathrm{~mm}$ x $7.7 \mathrm{~mm}$ x $4.3 \mathrm{~mm}$; amber is clear yellow-orange 532 with multiple layers and minor particulate content.

533 Etymology. The new species name refers to total body length, which is greatest of all known 534 Serphitidae. Epithet based on Latin word for "gigantic", giganteus. 
535 Type locality. Hukawng Valley, Kachin State, in Myanmar, upper Albian-lowermost

536 Cenomanian.

538 Diagnosis. Unique characters for new species include: total body size more than $3.46 \mathrm{~mm}$ 539 (significantly shorter in all other Mesoserphites); combined length of petiolar segments relatively 540 long, three-quarters of gastral length (although apex of gaster is not preserved); tarsi shorter than 541 corresponding femora; broad and deeply impressed sulcus near transscutal line interrupted by 542 raised areas posterior to notauli. Differential characters that separate new species from other 543 members of Mesoserphites include: head wider than long; ocelli forming weakly isosceles 544 triangle; compound eye occupying approximately one-third of head in lateral view; scape 545 approximately 2.2 times longer than its greatest width; right mandible with three teeth; left 546 mandible with two teeth; mesoscutellum convex; gaster apparently much shorter than mesosoma 547 in length; first petiolar segment comparatively short, about 1.9 times length of second segment; 548 first petiolar segment without globose, ring-like posterior part, and not rimmed anteriorly; first 549 petiolar segment with hamulus anterodorsally.

551 Description. Holotype total body length more than $\sim 3.46 \mathrm{~mm}$ (specimen incomplete with 552 posterior metasoma missing); mesosoma $\sim 1.76 \mathrm{~mm}$ in length; forewing $\sim 0.94 \mathrm{~mm} \mathrm{long}$ 553 (incomplete), and $\sim 0.53 \mathrm{~mm}$ wide; hind wing $\sim 0.96 \mathrm{~mm}$ long (incomplete), and $\sim 0.34$ mm wide; 554 metasoma $\sim 1.44 \mathrm{~mm}$ in length; gaster $\sim 0.79 \mathrm{~mm}$ long (incomplete) (Figs. 5-6).

555 Head: globose; gena slightly inflated; vertex highly mounded between lateral ocelli; frons 556 broadly concave; ocelli apparently forming isosceles triangular; median ocellus appears equal in 557 size to lateral ocellus, and separated from lateral ocellus by 2 OD; lateral ocelli rounded and 
558 nearly touching compound eye margin, separated by 4 OD; antenna 10-segmented and

559 proportionally short; flagellar articles measuring approximately: 106, 94, 101, 93, 99, 97, 87, and

$560105 \mu \mathrm{m}$; pedicel measuring approximately $151 \mu \mathrm{m}$; scape measuring approximately $333 \mu \mathrm{m}$ long

561 and $155 \mu \mathrm{m}$ wide; first flagellar and apical flagellar articles longest and equal in length;

562 flagellum flattened along posterior margin, and slightly serrated along anterior margin; first

563 flagellar article clavate or rounded anteriorly, and subsequent flagellar articles chalice-shaped;

564 apical flagellar article bud-shaped, and terminating in acute point; pedicel pear-shaped, and

565 approximately one-quarter length of scape; torulus slender, curved, and well-defined. Mandibles

566 deeply divided, with elongate and pointed teeth on robust mouthparts; right mandible with

567 middle tooth shorter than two others, ventral tooth longer and wider than dorsal tooth; left

568 mandible with ventral tooth much wider and longer than dorsal tooth; maxillary and labial palpi

569 not clearly visible, terminal maxillary palpomere broad and flattened, with acute point.

570 Mesosoma: has pronotum with costate surface structure; mesoscutum and mesoscutellum, shield-

571 shaped, and highly convex; mesoscutum with coriarious surface structure between curved

572 notauli; notauli forming V-shape which comes to point near anterior margin of mesoscutum;

573 mesoscutellum with middle part (between wings) forming transverse mounded strip, with

574 anterior row of foveate-reticulate sculpture then foveate surface structure; mesoscutellum slightly

575 concave adjacent to transverse raised strip, with confused rugulose surface structure;

576 mesopleuron nearly triangular, with row of fovea on anterior and posterior margins, and broadly

577 notched on posterodorsal margin; metanotum dorsally broad, concave, and with rugulose surface

578 structure; propodeum convex, with alveolate-rugulose surface structure separated by high

579 carinae. 
580 Wings: with incomplete preservation. Forewing without triangular pterostigma visible, missing 581 apical two-thirds; 1rs-r convex; C nebulous, straight; Sc+R tubular not reaching $\mathrm{C}$ basally; Sc+R, 582 slightly curved; Sc+R reaching bulbous 1 Rs before contact with pterostigma; M+1Rs tubular, 583 basal abscissa as wide as $\mathrm{Sc}+\mathrm{R} ; 2 \mathrm{M}$ curved in contact with 1m-cu and spectral, highly slender; $584 \mathrm{M}+\mathrm{Cu}$ slender tubular, broader apically than basally, not reaching $\mathrm{Sc}+\mathrm{R}$ basally, and broader 585 than $\mathrm{M}$ basally, slightly curved; $\mathrm{Cu}$ (basal abscissa) straight, as wide as $1 \mathrm{M}$, terminating in $\mathrm{CuP}$; $586 \mathrm{CuA}$ (distal abscissa) spectral; A tubular, short, slender, and fading midway toward base of wing. 587 Hind wing with Sc+R tubular, broader, relatively straight, and reaching Rs; Rs (basal abscissa) 588 nebulous, short, and straight; R tubular, as wide as Sc+R, slightly curved, and terminating in 589 bulbous expansion with three hamuli.

590 Legs: covered by semi-erect setae; procoxa equal in length and width, while mesocoxa slightly 591 longer than wide and metacoxa elongate; protrochanter bell-shaped, with meso- and 592 metatrochanter rectangular; femurs spindle-shaped; pro- and mesotibia elongate bell-shaped, and 593 metatibia bulbous posteroapically with numerous, long, semi-erect, broad setae; pro- and 594 mesotiabia with two spurs, with posterior spur longer and more slender than anterior spur, and 595 without metatibial spur apparent; metabasitarsus significantly longer than cumulative length of 596 other tarsomeres; pretarsus long with broad arolium between two simple, long, broad claws.

597 Metasoma: with gaster flattened ventrally and swollen dorsally (in lateral view); preservation is 598 incomplete, but two terga and three sterna are perceptible; lateral margins between tergites and 599 sternites without broad separation, difficult to observe boundaries; first petiolar segment shorter 600 in length, longitudinally carinate, with row of fovea between carina, and with notched 601 anterodorsal edge; second petiolar segment quadrangular, slightly curved dorsally and with two 602 straight edges between corners ventrally. 
Male: paratype AMNH_BU 667 does not have genitalia exposed externally, but it is very similar 604 in overall appearance to holotype specimen. As with other males in Mesoserphites, it possesses 605 seven flagellar articles and appears to be smaller than corresponding female. Highly curved 606 preservation position within surrounding amber gives male more pronounced 'hunch-backed' 607 appearance which may not be representative; posture also complicates measurements, male 608 apparently with $\sim 2.31 \mathrm{~mm}$ total body length, $\sim 354 \mu \mathrm{m}$ head length, $\sim 875 \mu \mathrm{m}$ mesosomal length, $609 \sim 521 \mu \mathrm{m}$ petiolar length, $\sim 563 \mu \mathrm{m}$ gastral length. Darker preservational colour of cuticle, 610 combined with bubbles adhering to surface of mesosoma, highlight coarser surface sculpture of 611 punctures on mesoscutum.

612

613

614 Mesoserphites engeli gen. et sp. n.

615 (urn:lsid:zoobank.org:act:49CE3893-D002-43D9-B7CC-A51959EE9821)

616

617 Material examined. Holotype RSKM_P3306.62 (female); paratype AMNH_Bu 1356 (male). 618 Holotype within polished amber piece including support epoxy, one of two amber pieces cut 619 from original block with dimensions of $10.3 \mathrm{~mm} \times 9.3 \mathrm{~mm} \times 4.4 \mathrm{~mm}$; amber is clear yellow with 620 flow lines delimiting runnel around specimens. Paratype within $12.8 \mathrm{~mm}$ x $16.9 \mathrm{~mm} \times 5.9 \mathrm{~mm}$ 621 block of epoxy embedded amber, and very well preserved with partially everted genitalia.

622

623 Etymology. The new species name is a patronym for Dr. Michael Engel, in recognition of his 624 substantial contributions to the Serphitidae. 
625 Type locality. Hukawng Valley, Kachin State, in Myanmar, upper Albian-lowermost 626 Cenomanian.

628 Diagnosis. Unique characters for species include: ocelli clearly forming equilateral triangle 629 (isosceles triangle in all other Mesoserphites spp.); head as long as wide or slightly transverse 630 (elongate in M. viraneacapitis, and more transverse in all other Mesoserphites spp.); mesoscutum 631 without visible notauli, highly convex, and in lateral view appearing somewhat mounded, 632 lacking pronounced sulcus along transscutal line; second petiolar segment with hamulus 633 posteroventrally (without hamulus posteroventrally in all other Mesoserphites spp.). Differential 634 characters for new species include: total body length $\sim 1.96 \mathrm{~mm}$; compound eye relatively large, 635 occupying approximately two-thirds of head in lateral view; lateral ocelli ovate, separated from 636 compound eye margin by less than 0.5 OD (nearly touching compound eye margin), and canted 637 posterolaterally, with lateral edge recessed into vertex; scape approximately 4.7 times longer 638 than its greatest width; combined length of petiolar segments relatively short, equal to one-third 639 of gastral length; sternum with four visible segments; first petiolar segment proportionally 640 longer, about 1.9 times length of second segment; first petiolar segment without globose, ring641 like posterior part, and not rimmed anteriorly; first petiolar segment with hamulus 642 anterodorsally; gaster slightly longer than mesosoma.

644 Description. Total body length $\sim 1.96 \mathrm{~mm}$; mesosoma $\sim 0.69 \mathrm{~mm}$ in length; forewing 645 approximately $0.94 \mathrm{~mm}$ long (incomplete), and $\sim 0.34 \mathrm{~mm}$ wide; hind wing $\sim 0.72 \mathrm{~mm}$ long, and $646 \sim 0.18 \mathrm{~mm}$ wide; metasoma $\sim 0.96 \mathrm{~mm}$ in length; gaster $\sim 0.66 \mathrm{~mm}$ long (Fig. 7). 
647 Head: with compound eye globose and rounded in lateral view, bearing minute, erect, fine setae;

648 gena moderately inflated; head with slight taphonomic distortion in holotype, width 1.2 times

649 length (proportion closer to 1.3 in male paratype) vertex slightly mounded between lateral ocelli

650 and with posterior margin rounded; frons slightly convex; median ocellus slightly smaller than

651 lateral ocellus, and separated from lateral ocellus by approximately 3 OD; antenna 10-

652 segmented; flagellar articles measuring approximately: 75, 42, 40, 54, 52, 57, 58, and $83 \mu \mathrm{m}$;

653 pedicel measuring approximately $70 \mu \mathrm{m}$; scape measuring approximately $164 \mu \mathrm{m}$ long and 35

$654 \mu \mathrm{m}$ wide; first flagellar article bell-shaped; subsequent flagellar articles appear shorter and nearly

655 chalice-like; apical flagellar article terminates in rounded acute point; pedicel pear-shaped,

656 approximately two-fifths of length of scape, and broader than first flagellar article. Mandibles

657 deeply divided with elongate, pointed teeth; details of closed mandibles not clearly

658 distinguishable; right mandible apparently with three stout teeth visible in holotype, teeth

659 progressively diminishing in size dorsally; left mandible apparently with two teeth visible in

660 holotype; maxillary palpus apparently as long as mandible, or perhaps longer than mandible,

661 four-segmented, and geniculate between second and third palpomere, with terminal palpomere

662 slender, long, and with acute point; labial palpus approximately half length of maxillary palpus,

663 apparently three-segmented and geniculate between first and second palpomere, with terminal

664 palpomere possessing highly inflated acute point.

665 Mesosoma: dark and without clear surface structure visible; mesoscutellum slightly convex

666 dorsally; mesopleuron bud-shaped, rounded along dorsal margin; metanotum convex, sunken

667 deeply in mesosoma; propodeum with many scabrous surface mounds.

668 Wings: not completely preserved. Forewing with triangular pterostigma equilateral in shape, and 669 with slender, elongate, posterior expansion of fuscous area adjacent to r-rs and Rs; C nebulous 
670 and Sc+R tubular; Sc+ R fusing apically with bulbous $1 \mathrm{Rs}+1 \mathrm{M}$, equal to width of adjacent costal

671 cell; $1 \mathrm{Rs}+1 \mathrm{M}$ and $\mathrm{Sc}+\mathrm{R}$ both dark and truncated in contact with pterostigma; $3 \mathrm{Rs}$ dark and

672 narrow tubular, basal curved towards anterior part of wing.

673 Legs: with moderately dense cover of fine setae; procoxa rounded, length and width equal, while

674 meso- and metacoxa longer than wide, and with two longitudinal carinae on lateral surface

675 equidistant from each other and from external margins of coxa; trochanters equal in length, and 676 appear laterally compressed; profemur shorter and wider than meso- and metafemur; tarsi longer

677 than corresponding femora; tibial spur formula 1-2-2, with protibial spur slightly longer than

678 meso- and metatibial spurs; probasitarsus equal to cumulative length of other tarsomeres; pro-

679 and metatarsomeres I, II and IV subequal in length and longer than mesotarsomeres; pretarsus

680 with short arolium, and long, thin claws.

681 Metasoma: gaster more ovate than teardrop-shaped, with punctured surface structure in dorsal 682 view; gaster slightly flattened ventrally in lateral view; tergum apparently with five segments, 683 with first tergite longer than second; second petiolar segment somewhat rectangular (ventrally 684 and dorsally straight) with hook-like posteroventral lip. Genitalia not everted, but apex of 685 ovipositor sheathe appears to be protruding from distal end of metasoma, probable female 686 specimen.

687 Male: paratype specimen is very similar to female holotype; male differences include having 688 seven flagellar articles, with first article slightly shorter than apical article; maxillary palpus as 689 long as mandible; head slightly transverse; first petiolar segment 2.1 times length of second, as 690 opposed to 1.9 times in type specimen; total body length $\sim 1.4 \mathrm{~mm}$. Parameres exposed in 691 paratype are clavate with two terminal setae that are elongate and erect; small, mound-like 692 projections anterior to parameres bear five, erect, apical setae, but details of region are unclear. 
Mesoserphites scutatus gen. et sp. n.

696 (urn:lsid:zoobank.org:act:DF1E1F2C-3C8B-497E-9607-93651773B394)

697

698 Material examined. Holotype RSKM_P3306.30a (female, wings partially folded and obscured); paratypes RSKM_P3306.30b (male), RSKM_P3306.30c (partial, probably female based on size), AMNH_BU 676 (female weathered specimen with exposed ovipositor apex). RSKM_P3306.30a and RSKM_P3306.30b within polished amber piece including support epoxy, one of three amber

702 pieces cut from original block, with dimensions of $10.4 \mathrm{~mm}$ x $7.6 \mathrm{~mm}$ x $6.5 \mathrm{~mm}$; amber is orange 703 with high particulate content. RSKM_P3306.30c in polished amber piece including support 704 epoxy, one of three amber pieces cut from original block, with dimensions of $10.4 \mathrm{~mm}$ x $7.6 \mathrm{~mm}$ $705 \times 6.5 \mathrm{~mm}$; amber is orange with high particulate content; specimens preserved alongside 706 syninclusion of $M$. viraneacapitis (RSKM_P3306.30d). AMNH_BU 676 is one of three pieces 707 cut from larger amber sample, embedded in epoxy block with dimensions of $6.3 \mathrm{~mm} \times 6.4 \mathrm{~mm} \times$ $708 \quad 2.3 \mathrm{~mm}$.

709

710 Etymology. The new species name refers to mesosoma-shape, which is inflated and shield711 shaped, using the Latin adjective scutatus, which means "shield-shaped".

712 Type locality. Hukawng Valley, Kachin State, in Myanmar, upper Albian-lowermost 713 Cenomanian. 
715

716

717

718

719

720

721

722

723

724

725

726

727 728

729

730

731

732

733

734

735

736

737

Diagnosis. Unique characters for the new species include: broad transcutellar furrow separating mesoscutum from mesoscutellum and isolating distinctive shield-shaped mesoscutellum; first petiolar segment with posterior margin notched dorsally to accept part of second segment (not present in other Mesoserphites spp.). Differential characters include: head wider than long; compound eye occupying approximately one-half of head in lateral view; lateral ocellus removed from margin of compound eye by $0.5 \mathrm{OD}$; left mandible with two large teeth, more robust and broad-based than teeth on right mandible; right mandible with three large teeth diminishing in size dorsally, and with dorsal and middle tooth closely spaced; antenna with eight flagellar articles, and first article is longest, slightly longer than pedicel; tarsi significantly longer than corresponding femora; gaster slightly shorter than mesosoma; sternum with six visible segments; first petiolar segment relatively short, about 1.6 to 1.8 times length of second segment; first petiolar segment without globose or ring-like posterior part, and not rimmed anteriorly first petiolar segment with hamulus anterodorsally.

Description. Female holotype RSKM_P3306.30a, with total body length $~ 1.96$ mm; mesosoma $\sim 0.67 \mathrm{~mm}$ in length; metasoma $\sim 0.93 \mathrm{~mm}$ in length; gaster $\sim 0.65 \mathrm{~mm}$ long. Male paratype RSKM_P3306.30c slightly more gracile, with total body length $\sim 1.92 \mathrm{~mm}$ (angled within amber); mesosoma $\sim 0.65 \mathrm{~mm}$ in length; metasoma $\sim 0.94 \mathrm{~mm}$ in length; gaster $\sim 0.62 \mathrm{~mm}$ long (Fig. 8).

Head: in female holotype globose in lateral view, with rounded compound eye; gena broad and slightly inflated; ocelli not clearly visible in holotype, apparently forming isosecles triangle with gentle mounding between ocelli; antenna 10-segmented in female, unknown in male; scape approximately $133 \mu \mathrm{m}$ long and $61 \mu \mathrm{m}$ wide; pedicel $\sim 82 \mu \mathrm{m}$ long and swollen apically, 
738 significantly broader than basal flagellar article; flagellar articles measure approximately 97, 66, $73951,41,46,46,51$, and $56 \mu \mathrm{m}$ in length, and become gradually broader from pedicel to 740 flagellomere six, then taper to acutely pointed apical flagellomere; flagellomere seven with 741 inclined stiff setae apically; left mandible bearing two broad-based teeth, plus diminutive dorsal 742 tooth, and bearing long setae; right mandible with three broad-based teeth that gradually increase 743 in length ventrally in series; maxillary palpus four-segmented and geniculate at midlength, 744 palpus approximately two-thirds of mandibular length; labial palpus either three- or four745 segmented, and approximately half of length of mandible.

746 Male: paratype similar to female but missing some details, with left side of head missing; gena 747 slightly inflated; antennae missing; mandibles deeply divided, with left mandible bearing two 748 broad-based teeth, plus diminutive dorsal tooth, and bearing long setae; right mandible not 749 distinguishable.

750 Mesosoma: with pronotum convex, with punctured surface structure; pronotum with row of 751 fovea surrounding external edges; mesoscutum highly convex, shield-shaped, with row of fovea 752 on anterior margin; notauli appear strongly curved and removed from lateral margins of 753 mesoscutum; mesoscutellum with scrobiculate surface structure anteriorly, and with rugose 754 surface structure posteriorly, separated from mesoscutum by broad transverse sulcus along 755 transscutal line; mesopleuron bud-shaped, flattened dorsally, with posterodorsal margin bearing 756 broad row of fovea; metanotum with scrobiculate surface structure, and apparently seven 757 depressions; propodeum convex with scabrous surface structure.

758 Wings: folded and incomplete in female holotype, with many details only visible in partial wings 759 (missing apices) preserved in male paratype - details provided here are based predominantly on 760 paratype, but appear consistent in holotype. Forewing with C nebulous, and costal cell very wide, 
761 width approximately five times that of nebulous $\mathrm{Sc}+\mathrm{R} ; \mathrm{Sc}+\mathrm{R}$ as wide as $1 \mathrm{M}$, nebulous adbasally;

$762 \mathrm{Sc}+\mathrm{R}$ fused apically with bulbous $1 \mathrm{Rs}$, and truncated in contact with pterostigma; $2 \mathrm{M}$ faintly

763 pigmented, broad, fuscous basally, but fading rapidly towards apex; $\mathrm{Cu}$ slightly concave.

764 Legs: covered by inclined setae; procoxa length and width equal, mesocoxa more ovate and 765 metacoxa elongate; procoxa with two central longitudinal carina on lateral surface equidistant 766 from each other and from external margins of coxa; pro- and mesotranchanter longer and broader 767 than metatrochanter; pro- and mesofemur shorter and narrower than metafemur; metafemur with 768 longitudinal depression on posterior surface; probasitarsus longer than, and metabasitarsus as 769 long as cumulative length of other tarsomeres; tarsomeres I and IV longer than II and III, and III 770 is smallest tarsomere; pretarsus with short arolium between two long, simple claws.

771 Metasoma: with combined length of petiolar segments equal to one-half of gastral length; gaster 772 covered with fine punctures and minute, erect setae; gaster in lateral view convex dorsally, and 773 nearly straight ventrally; tergum with five apparent tergites, and with second tergite longest, 774 slightly longer than first tergite; sternum without clear surface structure visible; lateral margins 775 between tergites and sternites difficult to observe; first petiolar segment nearly cylindrical, and 776 slightly curved, with anterodorsal expansion/pronounced anterodorsal lip; surface of first petiolar 777 segment with few, prominent, longitudinal carinae separated by fossulate sulci; second petiolar 778 segment bulbous, with flattened dorsal surface. Apex of ovipositor sheathe appears to be 779 protruding from distal end of metasoma, holotype probably female.

780 Remarks. Specimen AMNH_BU 676 is smaller than other female exemplars, with a total body 781 length of approximately $1.75 \mathrm{~mm}$; and it has moderately dense, suberect setae on the first and 782 second petiolar segments, with setae lengths equal to about half of the adjacent petiolar width. 783 These differences may suggest that the specimen belongs to a different species, but there is 
784 limited evidence to support this - the specimen exhibits significant taphonomic distortion and 785 weathering which may affect apparent dimensions, and highlight setae that are more subtle in 786 other representatives.

Mesoserphites viraneacapitis gen. et sp. n.

Material examined. Holotype RSKM_P3306.30d (male); paratype AMNH_BU 312 (male). Holotype in polished amber piece including support epoxy, one of three amber pieces cut from 794 original block, with dimensions $10.4 \mathrm{~mm}$ × $7.6 \mathrm{~mm}$ × $6.5 \mathrm{~mm}$; amber is orange with high 795 particulate content; preserved alongside syninclusions of M. scutatus (RSKM_P3306.30a-c). 796 Paratype in epoxy-embedded amber piece polished to dimensions of $10.9 \mathrm{~mm} \times 11.4 \mathrm{~mm} \times 4.3$ $797 \mathrm{~mm}$; amber is pale orange, clear, with prominent flow lines.

798 Etymology. The new species name refers to the head-shape which is similar to the mask of the 799 fictional character "Spider-Man"; it is a combination of the Latin noun vir- meaning "man" 800 combined with aranea meaning "spider", and capitis for the head-shape.

801 Type locality. Hukawng Valley, Kachin State, in Myanmar, upper Albian-lowermost 802 Cenomanian.

Diagnosis. Unique characters among Mesoserphites species include: head longer than wide 805 (equant in $M$. engeli and transverse in all other Mesoserphites); frons straight and sunken 806 compared to eye, and highly slender (not sunken, and wider in all other Mesoserphites spp.); 
clypeus subvertical (inclined in all other Mesoserphites spp.) and mandibles with relatively low

808 anterior projection when closed; mesoscutellum flattened (convex in all other Mesoserphites spp.); first petiolar segment relatively short, about 1.4 times length of second segment; first petiolar segment with globose ring-like posterior part and apparently rimmed anteriorly (not ring-like posterior part and not rimmed anteriorly in all other Mesoserphites spp.); first petiolar segment without hamulus anterodorsally (with hamulus anterodorsally in all other Mesoserphites spp.). Compared to other Mesoserphites species, new species has differential characters that include: total body length $\sim 1.85 \mathrm{~mm}$; compound eye occupying approximately one-third of head in lateral view; ocelli forming weakly isosceles triangle; left mandible with two long teeth; scape approximately 3.1 times longer than its greatest width; gaster slightly longer than mesosoma; combined length of petiolar segments slightly less than two-thirds of gastral length; sternum with five visible segments.

Description. Total body length $\sim 1.85 \mathrm{~mm}$; mesosoma $\sim 0.58 \mathrm{~mm}$ in length; forewing approximately $1.13 \mathrm{~mm}$ long, and $\sim 0.55 \mathrm{~mm}$ wide; hind wing $\sim 0.78 \mathrm{~mm}$ long, and $\sim 0.19 \mathrm{~mm}$ wide; metasoma $\sim 0.95 \mathrm{~mm}$ in length; gaster $\sim 0.60 \mathrm{~mm}$ long (Fig. 9).

Head: with compound eye forming high teardrop-shape, globose eyes bearing numerous, erect, fine setae; gena more inflated, especially near compound eye ventral margin and moderately inflated near vertex; median ocellus markedly larger than lateral ocelli; lateral ocelli nearly touching compound eye margin, weakly rounded, canted posterolaterally; antenna 9-segmented; flagellar articles measuring approximately: $89,73,75,67,73,59$, and $78 \mu \mathrm{m}$; pedicel measuring approximately $78 \mu \mathrm{m}$; scape measuring approximately $188 \mu \mathrm{m}$ long and $60 \mu \mathrm{m}$ wide; first flagellar article clavate; second flagellar article shorter, clavate, and following articles almost 
830 rectangular in outline; apical flagellar article terminates in acute point; pedicel elongate, pear831 shaped, and approximately one-fifth length of scape; scape length equal to height of compound

832 eye. Mandible closed, and bearing numerous, long, erect, fine setae; left mandible apparently 833 with two very long, pointed teeth, with dorsal tooth thinner than ventral tooth; right mandible not 834 clearly visible; maxillary palpus geniculate and terminating in slender and long rounded point, 835 only apical two segments visible, but palpus significantly shorter than mandible.

836 Mesosoma: without clear surface structure visible; mesoscutum, convex and slightly shield837 shaped, with punctate-reticulate surface structure; mesoscutellum with scabrous surface 838 structure; propodeum relatively straight, with scabrous surface structure.

839 Wings: forewing with equilateral triangle-shaped pterostigma, with 1rs-r and 2rs-r curved while $840 \mathrm{R}$ is straight; pterostigma with globose, triangular, posterior expansion of fuscous area adjacent 841 to r-rs and Rs; 2Rs nebulous, extending adbasally from pterostigma, forming long, straight 842 expansion reaching $2 \mathrm{M}$ (or seems to pass between $2 \mathrm{M}$ and $1 \mathrm{~m}-\mathrm{cu}$ crossvein and fading before $843 \mathrm{Cu}) ; 3 \mathrm{Rs}$ straight, extending apically from pterostigma, expanding and reaching anterior wing 844 margin apically; $\mathrm{C}$ nebulous, straight, with basal curvature; costal cell wider apically, with width 845 approximately three times that of $\mathrm{C}$, and narrower basally, less than half as wide as $\mathrm{C}$; tubular $8461 \mathrm{M}$ wider than $\mathrm{Sc}+\mathrm{R}$; tubular $\mathrm{Sc}+\mathrm{R}$, fusing apically with bulbous $1 \mathrm{Rs}$, and truncated in contact 847 with pterostigma; $\mathrm{Sc}+\mathrm{R}$ basally reaching $\mathrm{C}$ before bend; $\mathrm{M}+\mathrm{Cu}$ spectral, reaching apically $1 \mathrm{M}$ 848 and $\mathrm{Cu}$ in lowest point, straight; $2 \mathrm{M}$ fuscous and straight; $1 \mathrm{~m}$-cu crossvein slightly broader than 849 2M; $\mathrm{Cu}$ curved and terminating in $\mathrm{CuP}$ and $\mathrm{CuA}$ distally; $\mathrm{CuA}$ straight, fuscous, and wider 850 basally, then curved and gradually thinning to wing apex; CuP fading before reaching A; A 851 slightly curved and tubular. Hind wing lanceolate; nebulous Sc+R relatively straight; R wider 
852 than Sc+R, with three hamuli; Rs crossvein spectral and fading rapidly; posterior margin of wing

853 has small nebulous patch that may represent A, with patches erect setae along vein.

854 Legs: moderately robust and covered by numerous, inclined, fine setae; procoxa and mesocoxa 855 slightly longer than wide, and metacoxa elongate; protrochanter slightly shorter than 856 mesotrochanter and both are bell-shaped, while metatrochanter is elongate and globose; 857 metafemur with shallow and broad central depression; pro- and mesofemur more slender than 858 metafemur; profemur with rounded expansion on posterior surface; tibial spur formula 1-2-2, 859 with protibial spur fine and long, and meso- and metatibial spurs shorter; protibia shorter than 860 meso- and metatibia; basitarsus shorter than cumulative length of other tarsomeres; pretarsus 861 short, with heart-shaped arolium, and broad, long claws.

862 Metasoma: gaster covered with fine punctures and minute, semi-erect setae, ovate in dorsal view, 863 convex dorsally, and straight ventrally in lateral view; tergum with five segments, first tergite 864 longer than second; lateral margins between tergites and sternites difficult to distinguish, only 865 visible as fine line; first petiolar segment somewhat cylindrical, with anterior width slightly 866 greater than two-thirds of posterior width; first petiolar segment with numerous, fine carinae 867 separated by fine fossulae; second petiolar segment bulbous, with slightly flattened dorsal 868 surface. Male genitalia with parameres semi-clavate, apex moderately expanded; penis valves 869 gently swollen basally, and moderately separated.

870 Remarks. Paratype specimen AMNH_BU 312 differs from the holotype in having a head that 871 appears slightly transverse, as well as a body that appears more gracile, smaller $(\sim 1.63 \mathrm{~mm}$ in 872 total body length), and more setose. However, most of these differences can be attributed to 873 taphonomic distortion, because the specimen has shrivelled in the surrounding amber and 874 developed a wrinkled cuticle, as well as dark cuticle preservation highlighting translucent 
875 structures like setae. Observations of the paratype are limited to only one side, due to cracks and 876 syninclusions in the surrounding amber, but it is more parsimonious to consider this specimen

877 part of the $M$. viraneacapitis series, than a unique exemplar of a different species.

In general, $M$. viraneacapitis displays some characteristics of Supraserphitinae, including

879 the subvertical clypeus and petiolar segments that are closer to being even (first segment is only

8801.4 times length of second). However, the seven flagellar articles preclude the $M$. viraneacapitis

881 males described here from being the unknown male form of Supraserphites, which would

882 presumably have nine flagellar articles.

883

884 5. Discussion

885 Discovery of the two new genera Buserphites and Mesoserphites extends the diversity of the 886 family Serphitidae and builds upon the known diversity in Burmese mid-Cretaceous amber. 887 Despite the large number of serphitids that are commercially available from this deposit, the 888 diversity of these specimens seems to outstrip the samples that are currently available within the 889 AMNH and RSKM collections. Most of the new species discovered are only known from a 890 unique specimen (singleton), or very small specimen sets within museum collections. This may 891 lead to taxonomic uncertainty, and a lack of connection between males and females of each 892 species, until larger sample sets are described. Taxonomic uncertainty is exacerbated in our study 893 because many of the specimens in Burmese amber have undergone weak compression or 894 taphonomic shrivelling. This cuticle deformation varies between specimens, but it appears to be 895 more significant in small-bodied taxa, such as some of the species described herein. Distortion is 896 noticeable on cuticle surface structures within some specimens, so we have tried to emphasize 897 large-scale structural differences and specify regions of uncertainty within our descriptions. 
Many of the new species proposed herein have both female and male specimens assigned to them. These associations are difficult to support in cases where the sexes are not found as syninclusions. Consequently, future work and large sample sets may show that some of these specimens belong to unrecognized species, instead of being sexually dimorphic forms within the species proposed here. In previous work on Upper Cretaceous serphitid wasps (e.g., McKellar and Engel, 2010), males appear to have seven flagellar articles while females possess eight, and males appear to be slightly smaller or more gracile than their female counterparts. For the time being, and with the limited sample set that is available, we have refrained from erecting additional species in all cases where these features were the main differences between 907 specimens.

The new species within Buserphites n. gen. clearly differ from all known Serphitoidea in having: a flagellum with seven or eight segments (six-segmented in Jubaserphites, eleven-

910 segmented in Supraserphites, and twelve-segmented in Archeoserphitidae); a lateral ocellus that 911 is separated from the compound eye by 0.5 OD (nearly touching compound eye in Serphites, and

912 Mesoserphites n. gen.); a pronotum that extends to reach the tegula, and a pterostigma that is 913 distinct (pronotum not reaching tegula, and forewing with pterostigma indistinct in 914 Microserphites); a first petiolar segment that is 3.4 times the length of the second segment (two 915 times or less in Mesoserphites n. gen., Aposerphites, and Microserphites, or between two and 916 three times in Serphites); and a second petiolar segment with faint longitudinal striations 917 (apparently unique in Serphitoidea). The new species within Mesoserphites n. gen. can be 918 distinguished from other Serphitoidea based on having the following combination of 919 characteristics: a flagellum with seven or eight articles (six articles in Jubaserphites, and ten 920 articles in Supraserphites); the lateral ocellus nearly touching the compound eye (separated from 
921 eye by 1 OD in Aposerphites, and separated from eye by 0.5 OD in Buserphites n. gen.); a 922 pronotum that reaches the tegula, and a pterostigma that is distinct (pronotum not reaching 923 tegula, and the forewing with pterostigma indistinct in Microserphites); a first petiolar segment 924 that is less than two times the length of the second segment (more than two times in Serphites, 9253.4 times in Buserphites n. gen.); and a gaster with different lengths between first three terga 926 (first three terga similar in length in Aposerphites). An extensive cladistic analysis of 927 Serphitoidea will be necessary to fully test the limits and relationships of these genera, and to 928 determine which characteristics are phylogenetically informative or autapomorphies that may 929 refine our diagnoses. However, with the pace of recent work on this deposit, and the large 930 number of terminal taxa that still need to be described, this type of analysis would be better 931 performed after a preliminary account of all serphitoids has been completed.

The two new genera reported here have not been found in other Cretaceous amber 933 deposits, despite the fact that Serphitoidea have been one of the most extensively studied groups 934 of Hymenoptera in these assemblages. It remains unclear whether the Burmese amber 935 assemblage's important taxonomic and morphological diversity is most probably a consequence 936 of a particular palaeoenvironment, time averaging as a result of sampling multiple strata in the 937 Hukawng Valley, or palaeogeographic constraints that existed prior to the mid-Cretaceous in 938 Myanmar. The palaeoenvironment for this region during the Cretaceous was more tropical than it 939 is today, with average temperatures between 32 and $55^{\circ} \mathrm{C}$ south of $40^{\circ} \mathrm{N}$ latitude (Spicer et al., 940 1996; Grimaldi et al., 2002). In general, the Cretaceous was a hothouse interval with extensive 941 tropical belts. It seems that Burmese amber captured one of the most diverse terrestrial 942 assemblages in the Cretaceous, because it combined a large amount of resin production with a 943 diverse tropical fauna, and not because it represents an unusual coastal habitat (e.g., Xing et al., 
944 2018; Yu et al., 2019) conditions. Although many taxa are shared between Myanmar and other 945 Cretaceous sites (Grimaldi et al., 2002; Ross, 2019, 2020), or make a case for faunal exchange 946 between the Burmese amber forest and Asia (e.g., Oliveira et al., 2016; Fu et al., 2019), recent 947 research has suggested that groups such as Hymenoptera show substantial endemism. Eight 948 families of wasps are known solely from Burmese amber, and within Serphitidae the subfamily 949 Supraserphitinae is also restricted to this deposit (Zhang et al., 2018; Rasnitsyn and Ölm-Kühnle $9502018,2019 a, 2019 b)$. This points toward the development of endemic groups as the Western 951 Burma Block drifted toward its contact with Asia during the Cretaceous (Liu et al., 2016). The 952 new findings among Serphitidae reported herein seem to add further support to this pattern of 953 endemism at the genus-level; however, additional data are required from Asia to fully understand 954 the timing and direction of faunal exchanges in the region. Additional work will also be required 955 on the geology surrounding Burmese amber, to determine whether our impressions of this 956 assemblage are being shaped by a significantly longer depositional time or broader range of 957 depositional environments than other Cretaceous amber deposits with lower serphitid diversity.

\section{Conclusions}

960 This study expands the known diversity of the family Serphitidae in Burmese amber, through the 961 discovery of 7 new species, leading to the definition of two new genera. These new genera seem 962 to be endemic to the amber deposit, much like members of the recently described subfamily 963 Supraserphitinae. Moreover, this deposit appears to have preserved members of the small family 964 Serphitidae in large numbers and with greater diversity than the other Cretaceous amber deposits 965 where this family has been recovered. It is unclear whether this is a result of greater diversity and 966 abundance of serphitids in the Burmese amber forest, or if it is merely a result of the deposit 
967 being commercially mined on such a large scale. The presence of many singleton species within 968 our study seems to point toward diversity, as opposed to specimen availability, being the 969 dominant factor in this deposit. Overall, Burmese amber now contains the most species from the

970 family, with 12 species reported (including the studies of Rasnitsyn and Ölm-Kühnle, 2019a, $9712019 b, 2020 a, 2020 b)$. Additionally, preliminary work on existing museum collections suggests 972 that Burmese amber contains many additional new species within the family Serphitidae that 973 await description.

974

975 Acknowledgments

976 We are grateful to Editor Eduardo Koutsoukos and two anonymous reviewers for constructive 977 comments on this work, and to Michael Engel (University of Kansas, USA) for providing access 978 to specimens. Support was provided by the French scholarship "Fondation Rennes 1" (to M.H.), 979 the Natural Sciences and Engineering Research Council of Canada (2015-00681, to R.M.), and 980 by the Royal Saskatchewan Museum (to M.H.). This work is part of the M.Sc. thesis of Mélanie 981 Herbert, supervised by Didier Néraudeau (University of Rennes 1, France). 


\section{References}

Brues, C. 1937. Superfamilies Ichneumonoidea, Serphoidea, and Chalcidoidea. University of Toronto Studies, Geological Series 40, 27-44.

Cruickshank, R.D., Ko, K. 2003. Geology of an amber locality in the Hukawng Valley, Northern Myanmar. Journal of Asian Earth Sciences 21, 441-455. DOI: https://doi.org/10.1016/S1367-9120(02)00044-5

Daza, J.D., Stanley, E.L., Wagner, P., Bauer, A.M., Grimaldi, D.A. 2016. Mid-Cretaceous amber fossils illuminate the past diversity of tropical lizards. Science Advances 2(3), p.e1501080. DOI: https://doi.org/10.1126/sciadv.1501080

Engel, M.S. 2005. The crown wasp genus Electrostephanus (Hymenoptera: Stephanidae): discovery of the female and a new species. Polskie Pismo Entomologiczne 74(3), 317332.

Engel, M.S. 2015. A new family of primitive serphitoid wasps in Lebanese amber (Hymenoptera: Serphitoidea). Novitates Paleoentomologicae 13, 1-22. DOI: https://doi.org/10.17161/np.v0i13.5064

Engel, M.S., Grimaldi, D.A., Ortega-Blanco, J. 2011. Serphitid wasps in Cretaceous amber from New Jersey (Hymenoptera: Serphitidae). Insect Systematics and Evolution 42(2), 197204. DOI: https://doi.org/10.1163/187631211X560892

Engel, M.S., Perrichot, V. 2014. The extinct wasp family Serphitidae in Late Cretaceous Vendean amber (Hymenoptera). Paleontological Contributions 10, 46-51. DOI: https://doi.org/10.17161/PC.1808.15990 
1004 Fu, Y., Cai, C., Huang, D. 2019. First hairy cicadas in mid-Cretaceous amber from northern 1005 Myanmar (Hemiptera: Cicadoidea: Tettigarctidae). Cretaceous Research 93, 285-291. DOI: https://doi.org/10.1016/j.cretres.2018.09.022

1007

1008

1009

1010

1011

1012

1013

1014

1015

1016

1017

1018

1019

1020

1021

1022

1023

1024

Goulet, H., Huber, J.T. 1993. Hymenoptera of the world: an identification guide to families. Research Branch Agriculture $\quad$ Canada, 19-59. $\quad$ DOI: https://doi.org/10.1002/mmnd.19950420212

Grimaldi, D., Engel, M.S., Nascimbene, P. 2002. Fossiliferous Cretaceous amber from Myanmar (Burma): its rediscovery, biotic diversity, and paleontological significance. American Museum Novitates 3361, 1-72. DOI: 10.1206/0003-0082(2002)3612.0.CO;2

Harris, R.A. 1979. The glossary of surface sculpturing. Occasional Papers in Entomology California Department of Food and Agriculture Laboratory Services Supplement 28, 131. DOI: $10.5281 /$ zenodo.26215

Kozlov, M., Rasnitsyn, A. 1979. On the limits of the family Serphitidae (Hymenoptera, Proctotrupoidea). Entomologicheskoe Obozrenie [Revue d'Entomologie de l'URSS] 58(2), 402-416 [In Russian with English summary]. DOI: 10.5281/zenodo.26382

Li, L., Shih, C., Rasnitsyn, A., Li, D., Ren, D. 2018. A new wasp of Myanmarinidae (Hymenoptera: Stephanoidea) from the mid-Cretaceous Myanmar amber. Cretaceous Research 86, 33-40. DOI: https://doi.org/10.1016/j.cretres.2018.02.009

Liu, C.Z., Chung, S.L., Wu, F.Y., Zhang, C., Xu, Y., Wang, J.G., Chen, Y., Guo, S. 2016. Tethyan suturing in Southeast Asia: zircon $\mathrm{U}-\mathrm{Pb}$ and $\mathrm{Hf}-\mathrm{O}$ isotopic constraints from Myanmar ophiolites. Geology 44(4), 311-314. DOI: https://doi.org/10.1130/G37342.1 
1025

1026

1027

1028

1029

1030

1031

1032

1033

1034

1035

1036

1037

1038

1039

1040

1041

1042

1043

1044

1045

1046

1047

McKellar, R., Engel, M.S. 2011. The serphitid wasps (Hymenoptera: Proctotrupomorpha: Serphitoidea) of Canadian Cretaceous amber. Systematic Entomology 36(1), 192-208. DOI: https://doi.org/10.1111/j.1365-3113.2010.00559.x

Nascimbene, P., Silverstein, H. 2000. The preparation of fragile Cretaceous ambers for conservation and study of organismal inclusions. In Grimaldi, D. A. (ed.). Studies on fossils in amber, with particular reference to the Cretaceous of New Jersey. Backhuys Publishers, Leiden: 93-102.

Oliveira, I.S., Bai, M., Jahn, H., Gross, V., Martin, C., Hammel, J.U., Zhang, W.W., Mayer, G. 2016. Earliest Onychophoran in amber reveals gondwanan migration patterns. Current Biology 26(19), 2594-2601. DOI: https://doi.org/10.1016/j.cub.2016.07.023

Ortega-Blanco, J., Delclòs, X., Peñalver, E., Engel, M.S. 2011. Serphitid wasps in Early Cretaceous amber from Spain (Hymenoptera: Serphitidae). Cretaceous Research 32(2), 143-154. DOI: https://doi.org/10.1016/j.cretres.2010.11.004

Rasnitsyn, A.P., Ölm-Kühnle, C. 2018. Three new female Aptenoperissus from mid-Cretaceous Burmese amber (Hymenoptera, Stephanoidea, Aptenoperissidae): unexpected diversity of paradoxical wasps suggests insular features of source biome. Cretaceous Research, 91, 168-175. DOI: https://doi.org/10.1016/j.cretres.2018.06.004

Rasnitsyn, A.P., Ölm-Kühnle, C. 2019a. A new species of Supraserphites Rasnitsyn \& ÖhmKühnle from Burmese amber (Hymenoptera, Serphitidae: Supraserphitinae). Palaeoentomology 2(1), 13-16. DOI: https://doi.org/10.11646/palaeoentomology.2.1.3

Rasnitsyn, A.P., Ölm-Kühnle, C. 2019b. New serphitoid wasp Supraserphites draculi gen. et sp. nov. in Burmese amber (Hymenoptera, Serphitidae: Supraserphitinae). Cretaceous Research 99, 46-50. DOI: https://doi.org/10.1016/j.cretres.2018.12.006 
1048 1049

1050

1051

1052

1053

1054

1055

1056

1057

1058

1059

1060

1061

1062

1063

1064

1065

1066

1067

1068

1069

Rasnitsyn, A.P., Ölm-Kühnle, C. 2020a. Archaeoserphites engeli sp. nov., the first archaeoserphitid wasp in Burmese amber and first known archaeoserphitid female (Hymenoptera, Archaeoserphitidae). Palaeoentomology, 3(3), 235-239. DOI: https://doi.org/10.11646/palaeoentomology.3.3.3

Rasnitsyn, A.P., Ölm-Kühnle, C. 2020b. Two new species of Supraserphites (Hymenoptera, Serphitidae) in Burmese amber. Palaeoentomology, 3(2), 158-162. DOI: https://doi.org/10.11646/palaeoentomology.3.2.4

Ross, A.J. 2019. Burmese (Myanmar) amber checklist and bibliography 2018. Palaeoentomology 2, 22-63. DOI: https://doi.org/10.11646/palaeoentomology.2.1.5

Ross, A.J. 2020. Supplement to the Burmese (Myanmar) amber checklist and bibliography 2019. $\begin{array}{llll}\text { Palaeoentomology } & 3 & \text { (1) } & \text { DOI: }\end{array}$ https://doi.org/10.11646/palaeoentomology.3.1.14

Ross, A.J., Mellish, C., York, P., Crighton, B. 2010. Burmese amber. In: Penney, D. (Ed.), Biodiversity of Fossils in Amber from the Major World Deposits. Siri Scientific Press, Manchester, pp. 208-235.

Shi G., Grimaldi, D.A., Harlow, G.E., Wang, J., Wang, J., Yang, M., Lei, W., Li, Q., Li, X. 2012. Age constraint on Burmese amber based on U-Pb dating of zircons. Cretaceous Research 37, 155-163. DOI: https://doi.org/10.1016/j.cretres.2012.03.014

Smith, R.D., Ross, A.J. 2018. Amberground pholadid bivalve borings and inclusions in Burmese amber: implications for proximity of resin-producing forests to brackish waters, and the age of the amber. Earth and Environmental Science Transactions of the Royal Society of Edinburgh 107(2-3), 239-247. DOI: https://doi.org/10.1017/S1755691017000287 
1070 Spicer, R.A., Rees, P.M., Herman, A.B. 1996. The Cretaceous vegetation and climate of Asia:

1071

1072

1073

1074

1075

1076

1077

1078

1079

1080

1081

1082

1083

1084

1085

1086

1087

1088

1089

1090 some insights. Cretaceous Stratigraphy and Palaeoenvironments. Memoirs of the Geological Society of India 37, 405-433.

Xing, L., McKellar, R.C., Xu, X., Li, G., Bai, M., Persons IV, W.S., Miyashita, T., Benton, M.J., Zhang, J., Wolfe, A.P., Yi, Q. 2016. A feathered dinosaur tail with primitive plumage trapped in mid-Cretaceous amber. Current Biology 26(24), 3352-3360. DOI: https://doi.org/10.1016/j.cub.2016.10.008

Xing, L., Sames, B., McKellar, R.C., Xi, D., Bai, M., Wan, X. 2018. A gigantic marine ostracod (Crustacea: Myodocopa) trapped in mid-Cretaceous Burmese amber. Scientific Reports 8(1), 1-9. DOI: https://doi.org/10.1038/s41598-018-19877-y

Xing, L., Ross, A.J., Stilwell, J.D., Fang, J., McKellar, R.C. 2019. Juvenile snail with preserved soft tissue in mid-Cretaceous amber from Myanmar suggests a cyclophoroidean (Gastropoda) ancestry. Cretaceous Research 93, 114-119. DOI: https://doi.org/10.1016/j.cretres.2018.09.013

Yu, T., Kelly, R., Mu, L., Ross, A., Kennedy, J., Broly, P., Xia, F., Zhang, H., Wang, B., Dilcher, D. 2019. An ammonite trapped in Burmese amber. Proceedings of the National Academy of $\quad$ Sciences $116(23), \quad 11345-11350 . \quad$ DOI: https://doi.org/10.1073/pnas.1821292116

Zhang, Q., Rasnitsyn, A.P., Wang, B., Zhang, H. 2018. Hymenoptera (wasps, bees and ants) in mid-Cretaceous Burmese amber: a review of the fauna. Proceedings of the Geologists' Association 129(6), 736-747. DOI: https://doi.org/10.1016/j.pgeola.2018.06.004 


\section{Figure Captions.}

Fig. 1. (A) General serphitid wasp wing terminology. (B) General serphid wasp anatomical terminology, based on the drawing of M. engeli gen. et sp. n. Abbreviations of veins: A, Anal; C, Costal; Cu, Cubital; CuA, Cubital apical; CuP, Cubital posterior; 1M, Median 1 (basal); 2M, Median 2 (apical); $\mathrm{M}+\mathrm{Cu}$, between Median 1 and Cubital; $1 \mathrm{~m}+\mathrm{cu}$, between Median 1 and 2, and Cubital; R, Radial; 1Rs, Radial zone 1; 2Rs, Radial zone 2; 3Rs, Radial zone 3; 1r-rs, costal cell margin + pterostigma basal vein + pterostigma expension; 2r-rs, pterostigma apical margin; Sc, Subcostal. Abbreviations of anatomy: ba., basitarsus; cx., coxa; fe., femur; fla., flagellomeres; mlt., lateral margin between tergites and sternites; msp., mesopleuron; mst., mesoscutum; mstl., mesoscutellum; mtn., metanotum; oce., ocellus; ped., pedicel; ppd., propodeum; pro., pronotum; sca., scape; ster., sternite; ta., tarsus; ter., tergite; ti., tibia; tr., trochanter; ver., vertex.

\section{Fig. 2. Buserphites applanatus gen. et sp. n. holotype AMNH_Bu-1512 (probable female).}

(A) Lateroventral habitus view. (B) Specimen illustration showing venation. (C) Laterodorsal habitus view, arrow indicating right mandible. (D) Posterodorsal habitus view, , arrow indicating left mandible. Scale bars $1 \mathrm{~mm}$ in (A-D).

Fig. 3. Buserphites myanmarensis gen. et sp. n. holotype RSKM_P3306.61 (probable female).
(A) Dorsal habitus view. (B) Specimen illustration showing venation and cuticular sculpture. (C)

Lateral habitus view, partly masked by high particulate content in amber. (D) Ventral habitus 
1115 view, arrow indicating posterior extent of tergite 1 on ventral surface of gaster. Scale bars $1 \mathrm{~mm}$ 1116 in $(A-D)$.

1119 Fig. 4. Mesoserphites annulus gen. et sp. n. holotype RSKM_P3306.60 (male).

1120 (A) Posterodorsal habitus view. (B) Specimen illustration showing venation and cuticular 1121 sculpture. (C) Detailed view of gaster and wing venation in A, arrow indicates posterior extent of 1122 tergite 1 on ventral surface of gaster. (D) Anterolateral habitus view. (E) Predominantly ventral 1123 habitus view, arrows indicate muscle tissue preserved within legs. (F) Predominantly dorsal 1124 habitus view, partly obscured by drying lines in amber. Scale bars $1 \mathrm{~mm}$ in (A, B, D-F), 0.25 $1125 \mathrm{~mm}$ in $(\mathrm{C})$.

Fig. 5. Mesoserphites giganteus gen. et sp. n. holotype RSKM_P3306.63 (female).

(A) Dorsolateral habitus view. (B) Specimen illustration showing venation and cuticular 1130 sculpture. (C) Posterodorsal habitus view, showing surface of gaster truncated by polished edge 1131 of amber piece and infilled by clay minerals (arrow), and details of propodeal sculpture. (D) 1132 Lateral habitus view of body and ventral view of head. (E) Detailed view of wing venation and 1133 dorsal mesosomal sculpture from A. Scale bars $1 \mathrm{~mm}$ in $(A-D), 0.25 \mathrm{~mm}$ in $(\mathrm{E})$. 
1137

1138

1139

1140

1141

1142

1143

1144

1145

1146

1147

1148

1149

1150

1151

1152

1153

1154

1155

1156

1157

1158

1159

(A) Predominantly ventral habitus view of curled specimen. (B) Specimen illustration demarcating body regions in A. (C) Predominantly dorsal habitus view, highlighting details of mesosomal sculpture. (D) Lateral habitus view. Scale bars $1 \mathrm{~mm}$ in (A-D).

Fig. 7. Mesoserphites engeli gen. et sp. n. specimens.

RSKM_P3306.62 (female) holotype (A-F): Dorsolateral habitus view (A). Specimen illustration showing venation and body segmentation (B). Oblique anterior view of head, arrow indicates outer margin of closed mandibles (C). Detailed dorsal view of head in A, arrow indicates lateral ocellus (D). Detailed view of mesosomal dorsal surface in A (E). Ventrolateral habitus view (F). AMNH_Bu 1356 (male) paratype (G-I): Dorsal habitus view with wings bent over body, and wing from nearby aphidoid syninclusion (arrow) (G). Ventral habitus view, with inset of gastral apex (H). Lateral habitus view through significant overlying amber (I). Scale bars $1 \mathrm{~mm}$ in (A, B, $\mathrm{F}-\mathrm{I}), 0.25 \mathrm{~mm}$ in $(\mathrm{C}-\mathrm{E})$.

\section{Fig. 8. Mesoserphites scutatus gen. et sp. n. specimens.}

RSKM_P3306.30a (female) holotype (A,B):Ventrolateral habitus view with wings folded over specimen and obscured, horizontal arrow indicates right mandible, vertical arrow marks left mandible (A). Dorsolateral habitus view through thick overlying amber (B). RSKM_P3306.30b (male) paratype $(\mathrm{C}, \mathrm{D})$ : Dorsolateral habitus view, with wings truncated by polished surface of amber piece near their midlengths, and head truncated on left side (C). Specimen illustration highlighting surface sculpture (D). RSKM_P3306.30c (partial, probable female based on size) 
1160 paratype (E): Anterior view of head, body missing beyond middle of mesosoma, arrow marks 1161 right mandible. AMNH_BU 676 (female) paratype (F): Dorsolateral habitus view of weathered 1162 specimen with exposed ovipositor apex (arrow). Scale bars $1 \mathrm{~mm}$ in (A-D, F), $0.25 \mathrm{~mm}$ in (E).

1165 Fig. 9. Mesoserphites viraneacapitis gen. et sp. n. specimens.

1166 RSKM_P3306.30d (male) holotype (A-D): Ventrolateral habitus view (A). Specimen illustration 1167 showing venation and cuticular sculpture (B). Detailed view of head in A, with lateral ocellus 1168 marked by arrow (C). Posterodorsal habitus view. AMNH_BU 312 (male) paratype (E, F): 1169 Lateral habitus view (E). Specimen illustration outlining body regions and venation (F). Scale 1170 bars $1 \mathrm{~mm}$ in (A, B, D-F), $0.25 \mathrm{~mm}$ in (C). 


\section{Journal Pre-proof}
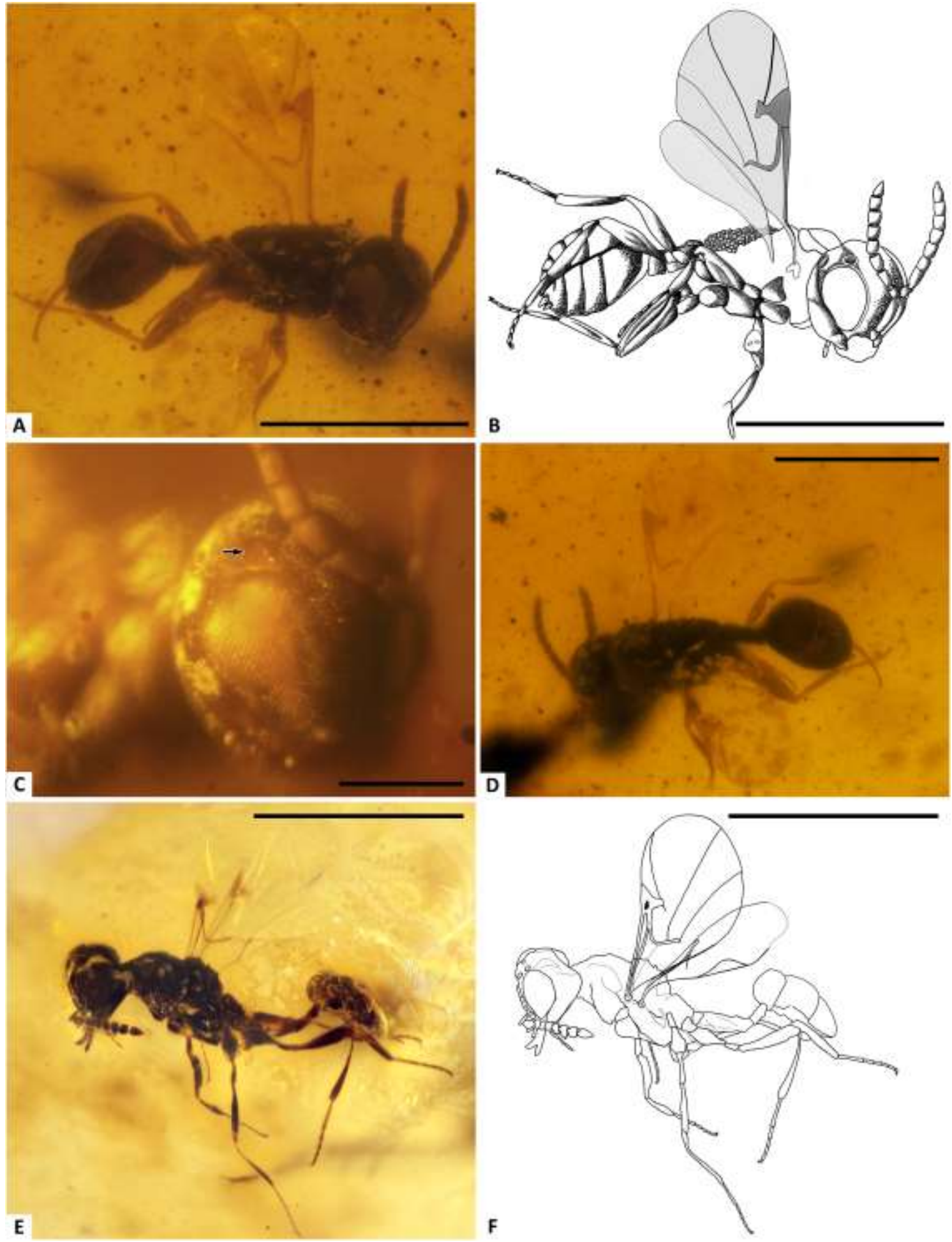

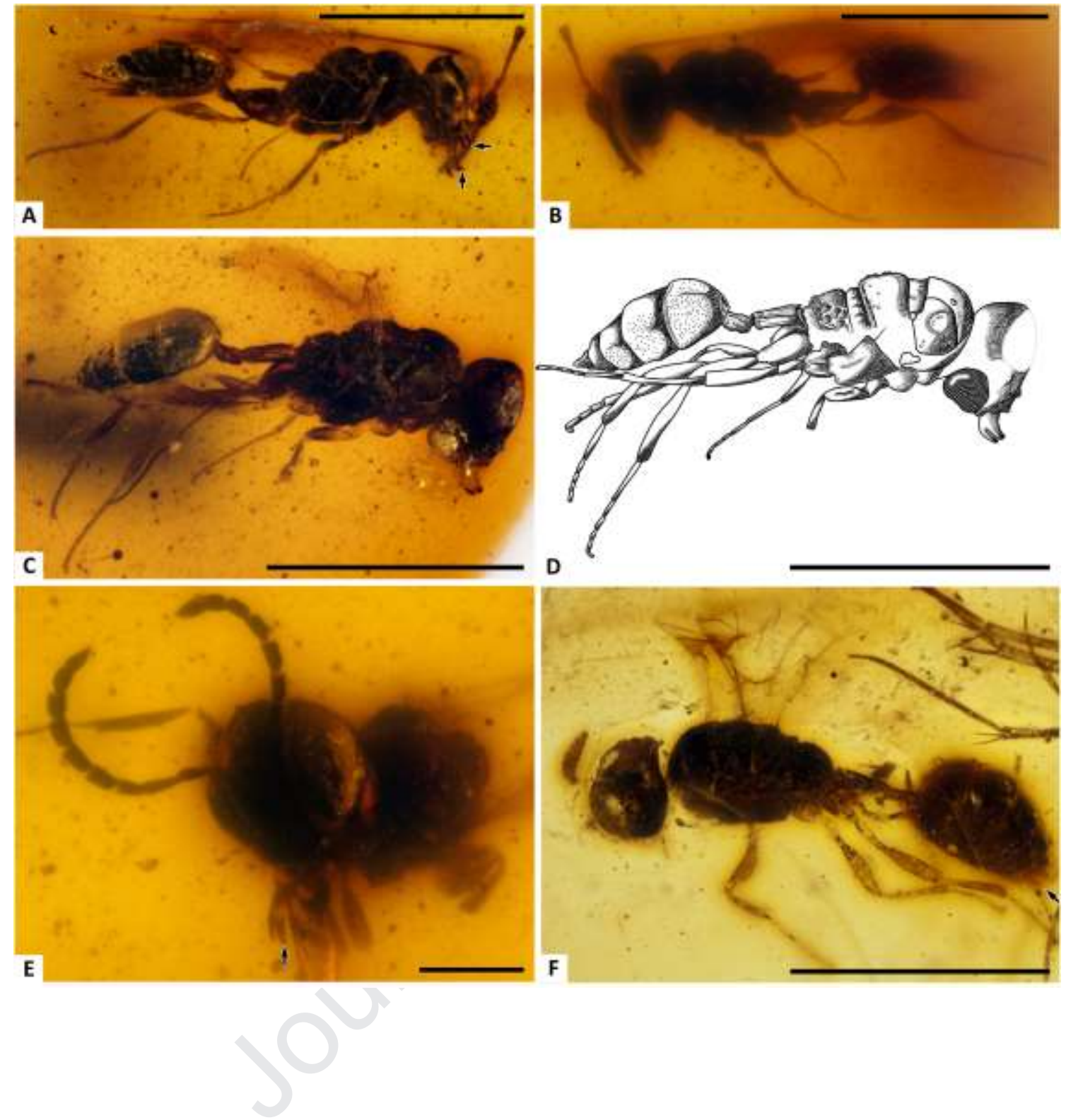


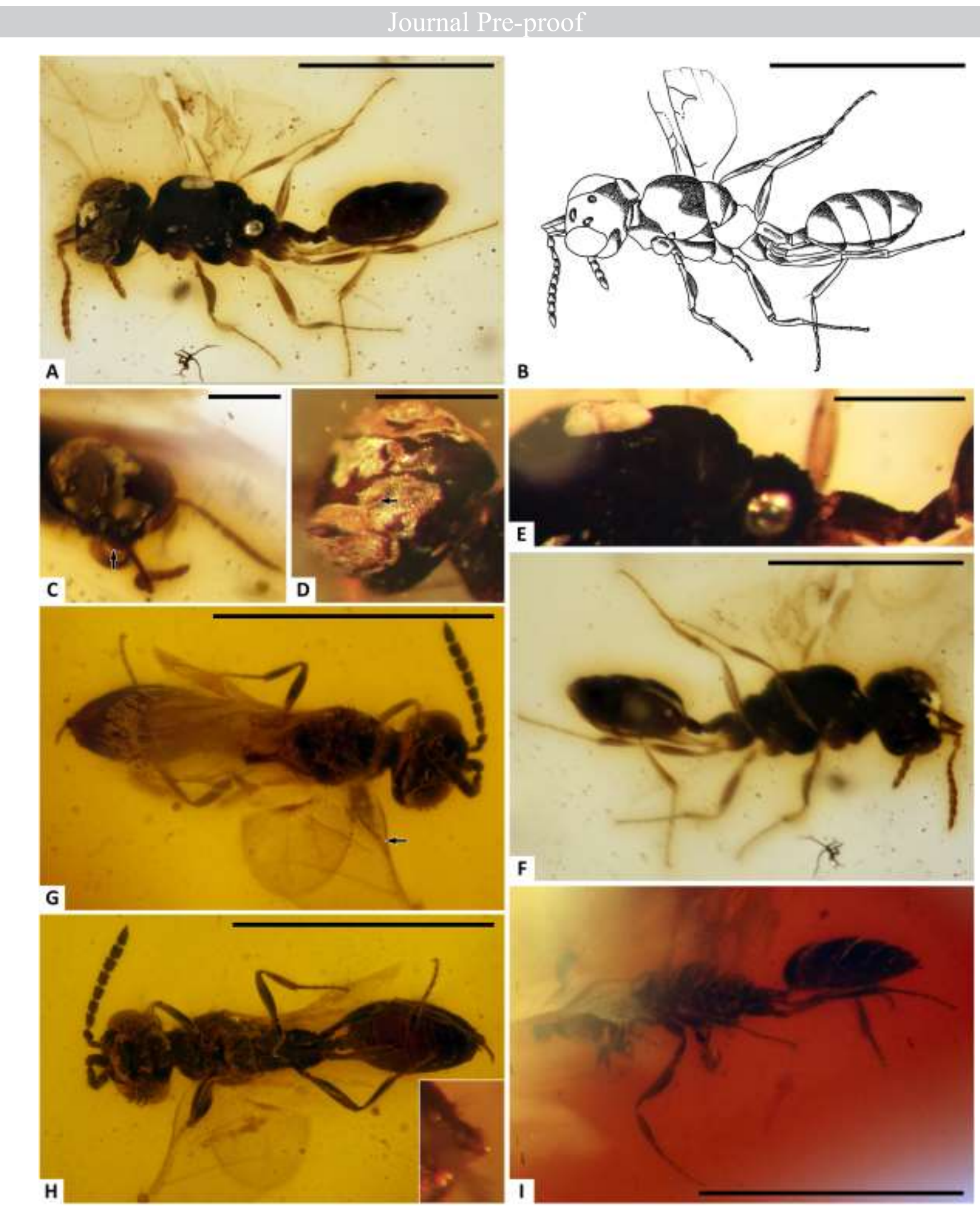



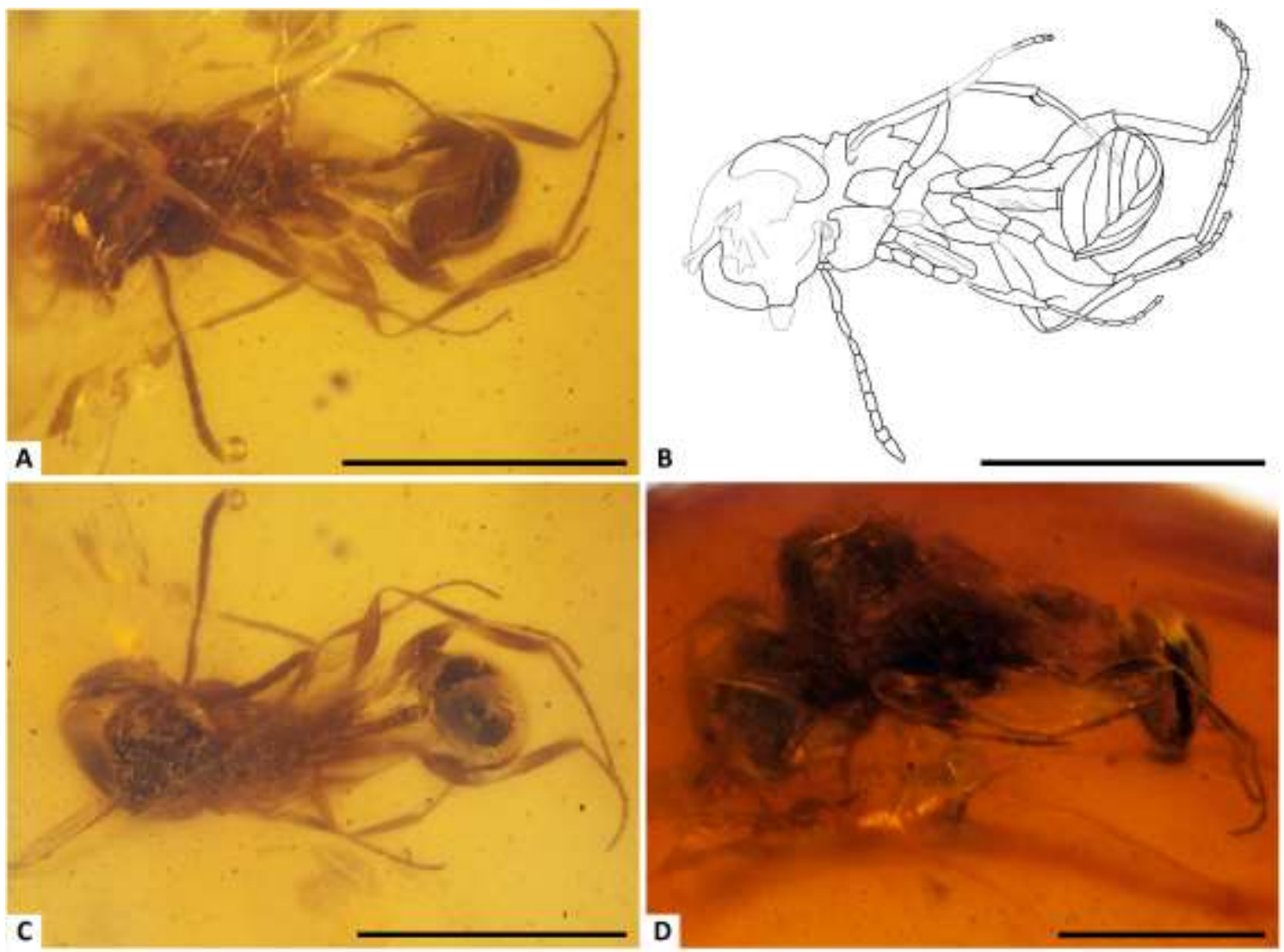


\section{Journal Pre-proof}

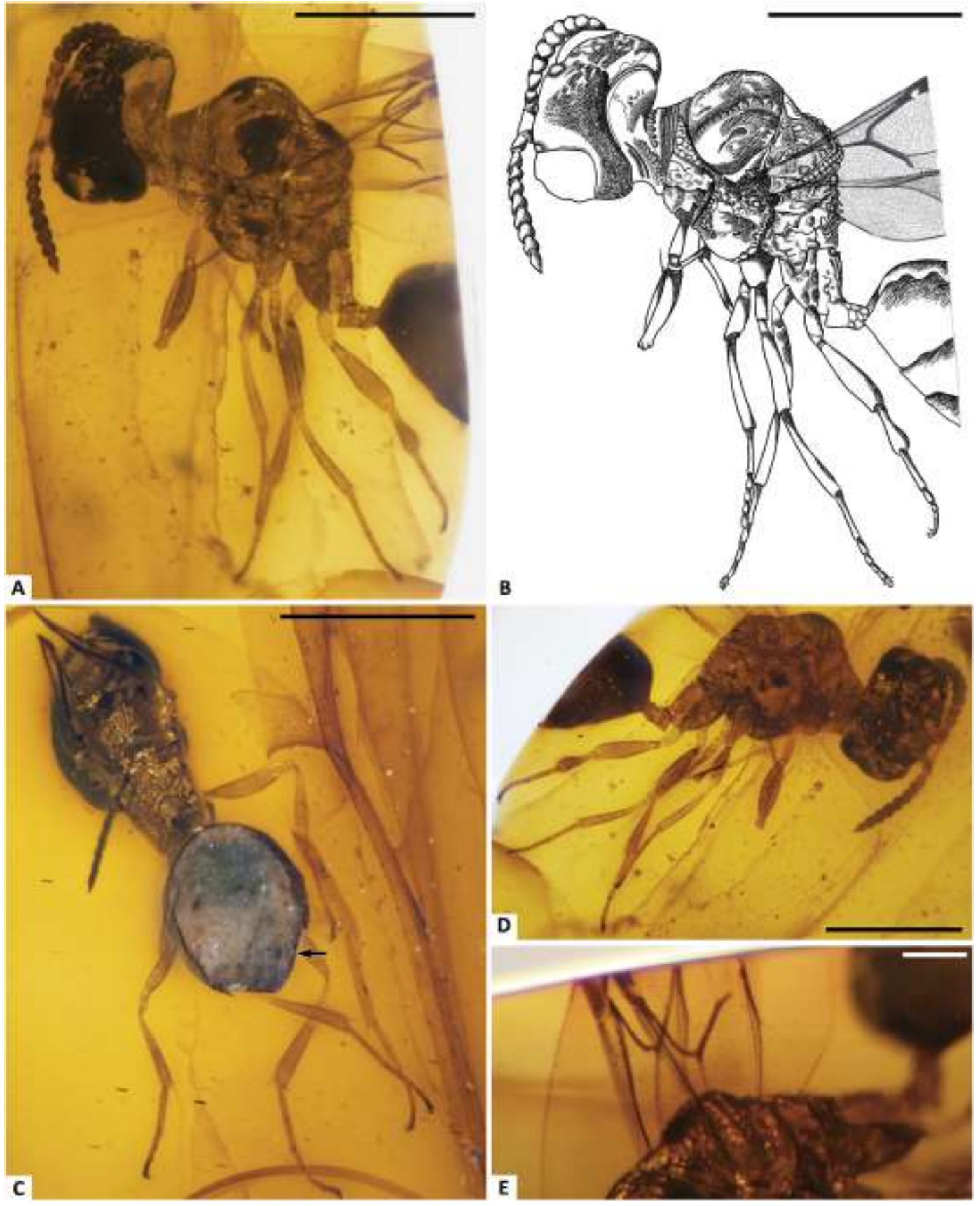




\section{Journal Pre-proof}
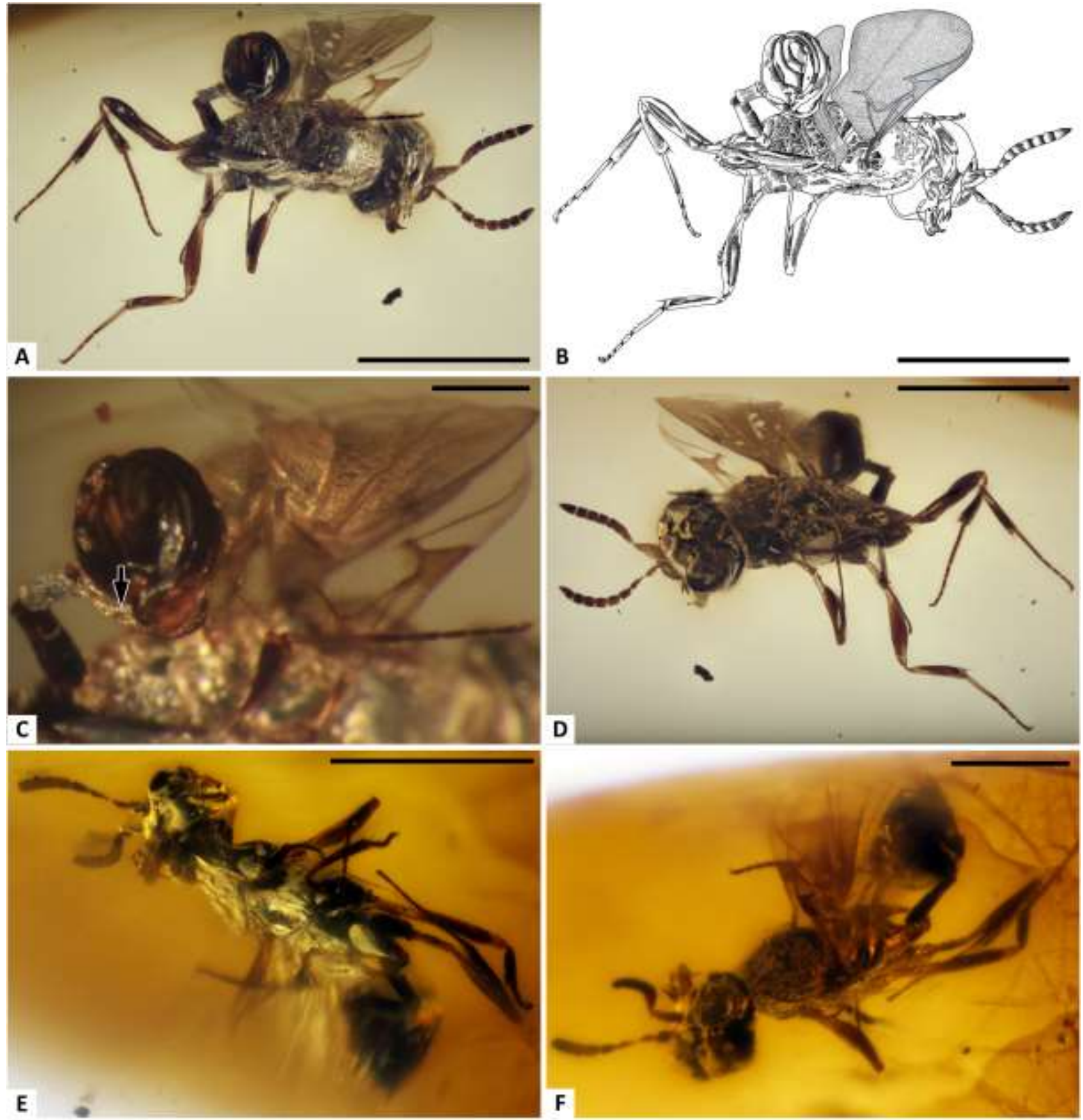

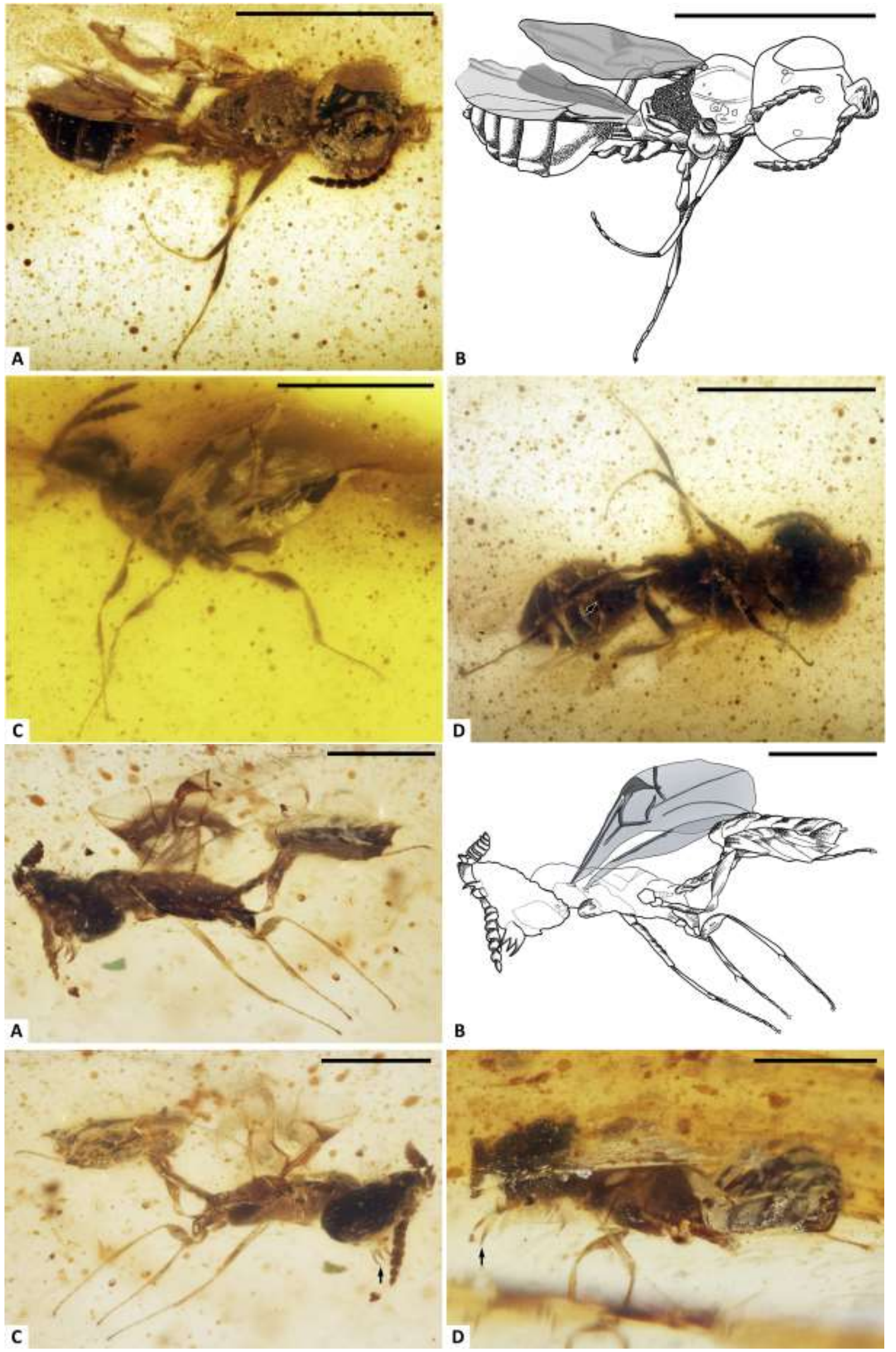

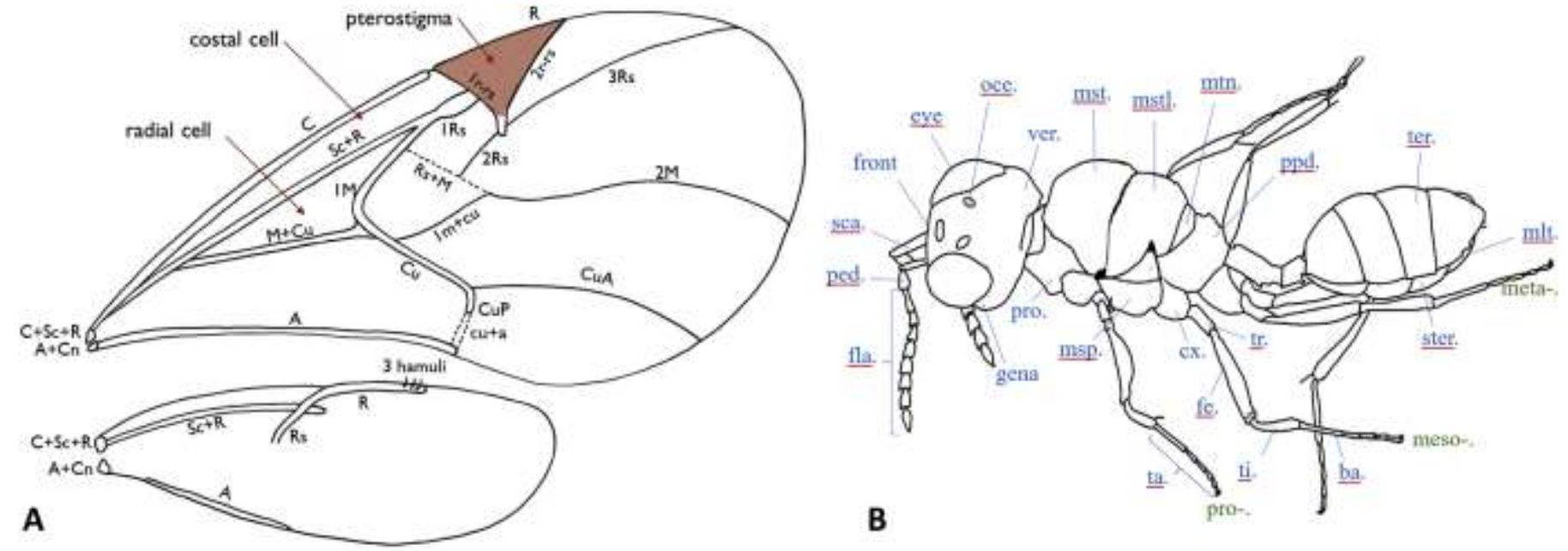


\section{Declaration of interests}

$\bigotimes$ The authors declare that they have no known competing financial interests or personal relationships that could have appeared to influence the work reported in this paper.

$\square$ The authors declare the following financial interests/personal relationships which may be considered as potential competing interests:

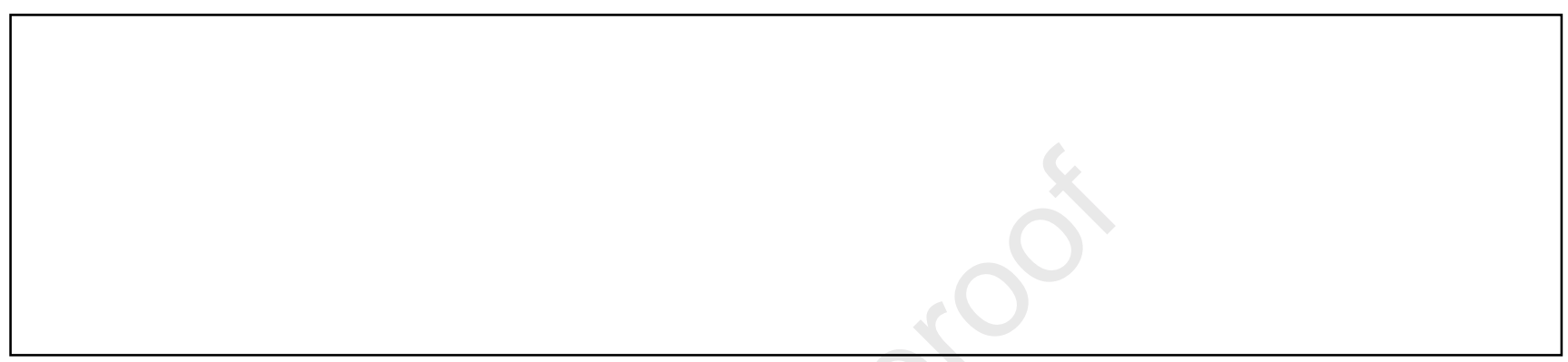

